\title{
SISTEMA TRADICIONAL RURAL DIANTE DE NOVAS ALTERNATIVAS
}

Alfio Brandenburg

ORIENTADOR: Prof. José Molina Filho

Dissertação apresentada à Escola Su perior de Agricultura "Luiz de Queí roz", da Universidade de São Pauloz para obtenção do título de Mestre em Sociologia Rural.

PIRACICABA

Estado de São Paulo-Brasil

Maio - 1981 


\section{AGRADECIMENTOS}

- a empresa de assistencia técnica e extensão RuRal DO PARANA (EMATER-PR), na pessoa do seu Diretor Presidente Eng ${ }^{8} \mathrm{Agr}^{8}$ HANS HENNING GUNTHER por patrocinar o curso que le vou a elaboração desta monografia.

- Ao Prof. JOSE MOLINA FILHO, pela orientação prestada na elaboração deste trabalho.

- Aos profs. MARIA IGNEZ GERRA MOLINA e thOMAS JOSEPH BURKE, pelas sugestões apresentadas na revisão dos originais.

- Ao Prof. JOSE Albertino R. ROdRigues pelas sugestões apresentadas na elaboração do quadro teórico que orien tou esta pesquisa.

- Aos professores do CuRso de mestrado em sociologia RURAL DA ESALQ/USP, que contribuiram com minha formação acadê mica. 
. ii.

A ILZE,

DEDICO 
. $i$ i

\section{I $N$ D $D$ I C E}

Pàgina

1. INTROOUÇĀO . . . . . . . . . . . . . . . . . . . . . . 1

1.1. O problema e sua importāncia. . . . . . . . . I 1

1.2. Objetivos do trabalho............ . . 6

2. o projeto fruticultura . . . . . . . . . . . . . . . 8

2.1. A viabilidade da atividade da Fruticultura. . 12

2.2. Perspectivas de mercado para a Fruticultura. . 14

3. orientaçao teórico-metooológica. . . . . . . . . . 22

3.1. Revisão de literatura. . . . . . . . . . 22

3.2. Orientação teórica. . . . . . . . . . . . 26

3.3. O Projeto Fruticultura como objeto de análise 30

3.4. Aspectos operacionais. . . . . . . . . . . . 42

3.5. Hipótese básica. . . . . . . . . . . . 45 45

4. contexto e procedimento do estudo. . . . . . . . . 46

4.1. Area de estudo. . . . . . . . . . . . 46 46

4.2. Descrição geral da área. . . . . . . . . 50

4.2.1. Aspectos socioculturais. . . . . . 50

4.2.2. Meios e condicionantes básicos da situação. . . . . . . . . . . 56

4.3. A pesquisa. . . . . . . . . . . . 60

4.3.1. Material de pesquisa. . . . . . . 660

4.3.2. Entrevistas. . . . . . . . . . . 60

4.3.3. Critério para estratificação dos produ tores entrevistados. . . . . . . ". 62

4.3.4. Estratificação dos entrevistados. . . 64

5. ANÁlise e INTERPRetaçÃo . . . . . . . . . . . . . 68

5.1. Função adaptação. . . . . . . . . . . . . 69

5.1.1. Adaptação ao meio natural. . . . . . 70

5.1.2. Adaptação às atividades propostas. . . 71 
Pàgina

5.2. Função consecução de metas. . . . . . . . . 73

5.3. Função integração . . . . . . . . . . . . 75

5.4. Função latência. . . . . . . . . . . . 85

5.5. Fruticultura como nova alternativa. . . . . 86

5.5.1. Significado da Fruticultura para os produtores rurais. . . . . . . . 9 93

5.5.2. Fatores condicionantes relacionados com a consolidação da atividade Fruticultura................. 96

5.6. Resultados obtidos pelo Projeto e consequên cias da atividade Fruticultura para as categō rias de produtores envolvidas. Verificação da hipótese básica.............. 101

6. CONClusdes. . . . . . . . . . . . . . . . . 110

7. Bibliografia ...................... 115

8. ANEXOS ............................. 120 


\section{LISTA DE TABELAS}

Tabela

Pàgina

1 - Análise económica referente a l ha de maçã no Paraná - 1977 .............

2 - Análise económica referente a 1 ha de amei xa no Paraná - $1977 .$. . . . . . . .

3 - Análise económica referente a l ha de pêssego no Paraná - $1977 .$. . . . . . .

4 - Maçã - Evolução de importações brasileiras..

5 - Situação da cultura da maçä nos Estados do Sul do Brasil - 1977. . . . . . . . .

6 - Comercialização de frutas no CEAGESP em 1975 - Percentual em função da origem. .

7 - Estrutura fundiária de Iratí - 1972. . .

8 - Máquinas agrícolas existentes no Município de Iratí - 1975/1976. . . . . . .

9 - Situação dos Produtores Genuínos entrevista dos, em relação a mão-de-obra, grau de participação no mercado e grau de especiali zação. . . . . . . . . . . . . . . . . .

10 - Frutiferas plantadas em Iratí, segundo a ca tegoria de produtores...........

11 - Projetos de frutíferas aprovados pelo IBDF,

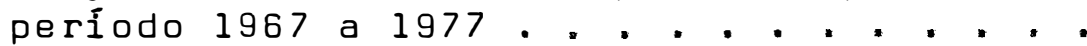

12 - Projetos de Fruticultura aprovados pelo IBDF no Estado do Paraná, por culturas - Pe ríodo 1967 a $1977 . .$. . . . . . . . 
. $v i$.

\title{
SISTEMA TRADICIONAL RURAL DIANTE DE NOVAS ALTERNATIVAS
}

\author{
Alfio Brandenburg
}

ORIENTADOR: Prof. José Molina Filho

R E S U M O

Este trabalto estuda aspectos relacionados com a prätica de novas atividades na agricultura, através da ană Zise de um Projeto de Intervencão no Meio Rural, executado pe La EMATER-PR: o Projeto Fruticultura.

o estudo é baseado nas contribuigões teöricas de MERTON e PARSONS e interpreta a situagão em que o produtor rural pratica suas atividades a partir da nogão de sistema de ação social, desenvolvido por Parsons. A situação empirica em que age o produtor é reconstruida analiticamente, concentrando-se no modelo AGIL.

os dados foram coletados através de observacões diretas e entrevistas não diretivas, orientados por um roteiro de pesquisa. Para a coleta de dados escolheu-se o lo cal de Irati, situado na Região sul do Paraná. Iratì é povoado por colonos descendentes de emigrantes europeus que pra ticam uma agricultura tradicional em pequenas e médias pro- 
. vii.

priedades agricolas.

Conclue-se que o Projeto Fruticultura mostra-se funcional para a sociedade. Suas metas de aumentar a produ\&ão de frutas para abastecer o mercado interno e reduzir o vo Zume de importações vêm sendo atingidas.

A partir dos resultados já alcangados, a análi se do projeto identifica basicamente duas categorias de produ tores beneficiadas - O Empresário Familiar e o Fruticultor Parcial - e esclarece o sistema de ação do Empresário FamiZiar.

Conclue-se que a fruticultura é explorada sempre que os componentes situacionais favorecem a realizacão econômica do produtor, devendo-se destacar os aspectos relativos à comercialização, área da propriedade, outras alternativas de exploracão, recursos financeiros e transporte.

Nos limites em que é cultivada, a fruticultura é percebida como funcional para os Empresários Familiares, mas a análise do projeto indica ser mais funcional para os Fruticultores Parciais. Estes diferentes resultados funcionais de nota tendência do projeto provocar um maior desajuste sócioeconômico no setor rural, embora na forma como se realiza demonstre-se funcional para a sociedade.

Da anälise do sistema de ação do Empresário Fa miliar conclue-se, ainda, que duas ordens de fatores estão re Zacionados com a prática de novas atividades agricolas:(1) os aspectos subjetivos, internalizados pelo produtor, (2) os as 
. viii.

pectos situacionais ou externos relacionados com condicionan tes empiricos. Estas duas ordens de aspectos permitem melhor compreender o fenômeno "resistência" a novas präticas agrícolas, que representa um padrão de orientacão tradicional, mas apenas enquanto produto resultante da história do produtor com a situação.

A anälise das diferentes dimensões funcionais mostra que o sistema de as̃ão do Empresário Familiar mantém sua unidade mediante a conjugąão de meios modernos e tradicionais de produção e desse modo atende os requisitos de insergão na sociedade. 
. $i x$.

\section{TRAOITIONAL RURAL SYSTEM FOWARD OF NEW ALTERNATIVES}

Alfio Brandenburg

ORIENTADOR: Prof. José Molina Filho

$S U M M A R Y$

This paper is concerned with the introduction of new exploitation alternatives in agriculture, through a Rural Setting Intervention Project - The Fruit Grop Project being carried on by EMATER-PARANA.

This study is based on the theoretical

contribuitions of Merton and Parsons, and interprets the famer's behavior from the Parsonian stand point. Accordingly, the context in which the famer acts is analitically constructed following the "AGIL" model.

The data were colected through direct observation and non-obstrusive intervies. The setting is the Municipio of Irati, Sourthern Paranä State. It is inhabited by peasants of European ascendency practicing a Zow-technology agriculture and living in smalz and medium size farms.

The study concludes that the Fruit Crop Project is functional to the society. Its goal of increasing fruits production has been achieved, as well as the supplying 
of the internal demand, reducing importation needs.

From the achieved results the study identifies two basic farmer categories, which benefit from the Project: The Family Farmers and the Partial Fruit Growers.

The Study finds that Fruit Crops are adopted if the situational components benefit the farmer's profitability Among these components the most outstanding are: farm size; other crops alternatives; financial suport; and transportation.

Fruit Crops are perceived as functional by the Family Farmers, but the objective project analysis shows they are more functional to the Parcial Fruit Growers. These different functional attributes uncover the project tendency to promote a socio-economical desequilibrium in the rural area, although it seems to be functional to the society. The Family Farmers action system analysis concludes that two kinds of factors are related to the practice of new agricultural activities: (1) the subjective aspects internalized by the farmer; and (2) the situational or external aspects related to empirical constraints. These two kinds of aspects permit a better comprehension of the resistency to new agricultural technologies, which represents a traditional orientation pattern, and a produce from the historical relationship betweem actor and his situation. 
$x i$.

The analysis of the different functional

dimensions shows that the Family Farmers action system survives because it combines modern and tradicional methods of farming and this is the way by which it is incorporated in the society. 


\section{INTRODUÇÃO}

\subsection{O problema e sua importância}

As transformações da sociedade brasileira, decorrentes da expansão industrial, têm exigido dos diversos se tores da economia ampla reorganização fazendo-os assumir funçöes bem específicas. A divisão social do trabalno torna-se cada vez mais complexa, principalmente nos setores mais dinâ micos da economia, onde se verifica uma crescente especializa ção de atividades. Essa situação requer dos diversos setores maior eficiéncia e, consequentemente, impõe transformações fun damentais, refletindo-se na organização da produção.

O setor agrícola participa dessas transformações ao oferecer maior produção de gêneros alimentícios, visan do abastecer uma população crescente, não engajada na produ 
ção de alimentos. Além desta função, forriece matérias-primas para a indústria e gera excedentes para exportação. Maior efí ciência é requerida do setor rural para aumentar a produção e a produtividade, visando capacitá-lo a acompanhar o crescimen to do parque industrial e a geração de divisas para o País. Assim, sua modernização é tida como necessāria,embora não su ficiente, trazendo implícita a necessidade de capitalização.

O setor agrícola também se constitui num merca do potencial importante para os produtos industriais e para os serviços face ao grande contingente populacional ainda ocu pado na agricultura. Mas a aquisição de modernos instrumentos de produção e a expansão do mercado para bens manufatura dos são grandemente limitadas pelo poder aquisitivo da popula çäo rural, o que implica na necessidade de aumentar sua renda, principalmente através da colocação dos produtós agrícolas no mercado com relação de trocas mais vantajosas. Desse modo, a interdependência entre os setores agrário e uribano-industrial se verifica, principalmente, através da inserção do setor rural no mercado de produtos com relações de trocas mais simétricas.

O crescimento acelerado das últimas décadas, concentrando no polo urbano, fez com que o processo de trans formação do setor rural se moldasse para favorecer mais o se tor urbano que o próprio meio rural. Desta forma, embora par te da agricultura tenha atingido um certo grau de capitalização (principalmente em torno de grandes culturas tais como so 
ja, café e cana-de-açúcar), conserva um baixo padrão técnico de produção (principalmente nas culturas de alimentos, feijão, milho, mandioca...J, com baixa produtividade, mantendo rela ções de produção arcaicas como a parceria, o colonato e o pe queno arrendamento.

A expansão do capitalismo na agricultura e a concentração da propriedade da terra tendem a liberar um volu me crescente de mão-de-obra. Esse fato, por um lado, vem be neficiar a indústria com aumento da oferta de mão-de-obra,mas, por outro, nas condições atuais, tende a gerar tensões e difi cultar a manutenção de níveis mínimos de bem-estar social dos trabalhadores rurais e dos que migram para as cidades.

O contingente populacional liberado do setor agrícola acha-se desqualificado profissionalmente,para enfrentar um mundo urbano exigente em mão-de-obra especializada. Além dis so, há que se considerar que o parque industrial, bem como os de mais setores urbanos, nem sempre tem oferecido um nümero suficiente de empregos com uma remuneração que permita ao migrante desfrutar de uma posição social sequer equivalente a do seu local de origem. Isto tem provocado desequilibrios que se refletem na emergência de bolsões de pobreza, quando não de condições sub-humanas de sobrevivência, deixando segmentos da população à margem do processo de desenvolvimento. Essa si tuação configura-se como paradoxal num País com grande exten são de área cultivável, que está a exigir determinados produ tos, ainda importados. 
Torna-se, assim, necessária a intervenção planejada com base na realidade, através de instrumentos capazes de Iiminar desequilfbrios emergentes na sociedade. Um dos aspectos a ser considerado nos instrumentos de superação desses desequilfbrios, seria oferecer ao homem do campo condições de se fixar ao seu meio e se integrar numa economia de mercado, reajustando o processo produtivo e aumentando sua ren da líquida. Para concretizar esse objetivo, órgãos vinculados ao Estado já atuam através de planos regionais de intervenção. E o caso da Empresa de Assistência Técnica e Extensão Rural do Paraná* (EMATER-PARANA), que há vários anos vem intervindo naquele estado com vistas ao desenvolvimento da agricultura. Essa Empresa vem executando, desde 1974, o projeto fruticultura que constitui um dos seus instrumentos de intervenção no meio rural. "Embora em seu início a implantação do projeto tenha sido realizada diretamente pela Secretaria da Agricultura do Estado do Paraná, hoje está a cargo da refe rida empresa vinculada a esta mesma secretaria.

A EMATER-PARANÁ visa explicitamente, através da implantação e expansão da fruticultura: a) a fixação da população rural ao seu meio; b) o aumento da produção e da produ-

* A EMATER-PARANA foi instituida para absorver os serviços prestados pela ACARPA - Associação de Crédito e Assistência Rural do Paraná. 
tividade, dada a necessidade constatada de abastecer o setor näo-agrícola e de alcançar a auto-suficiência em determinados produtos frutícolas, tentando diminuir o volume das impoI tações e cl o aumento da renda da produção,capacitando-a para melhor participar nas relaçōes de troca de produtos e, con sequentemente, melhorar seu nível de vida (DIRETRIZES DE AÇÃo, ACARPA, 19773.

Na versão do projeto, a proposta de uma nova linha de exploração se viabiliza na medida em que,por um lado, visa contribuir para a fixação do homem do campo, ajustando-o socioeconomicamente ao seu meio de origem è ordem de integração societária e, por outro lado, atende aos reclamos da sociedade, no sentido de abastecer o mercado e diminuir o volume de importação.

o que se pode questionar, no entanto, é se os objetivos explicitados pelo projeto vēm sendo atingidos na realidade. Ou, antes disso, quem estaria adotando a nova linha de exploração agrícola e se beneficiando com o projeto? Todas as categorias de produtores? Se não, por que? Que respostas poderiam ser dadas a estas perguntas? Seria desinteresse ou resistência a novas alternativas de produção por par te de alguma categoria de produtores? Ds meios para a consoli dação da atividade estariam ajustados para favorecer todas as categorias ou estariam concentrados apenas em torno de uma ou de outra categoria?

o questionamento em torno do desempenho do pro 
.6.

jeto nos conduz ao estudo de "aspectos relacionados a novas práticas na agricultura". Ao se intervir no meio rural, mediante a proposição de novas alternativas de exploração, deve-se compreender antes de mais nada, sob que condiçōes estas alternativas passam a ser exploradas. E isto que se pretende verificar através da análise do projeto fruticultura. Analisando os resultados até agora obtidos, pretende-se entender as condições ou fatores que levaram os produtores adotar ou rejeitar a nova linha de exploração e quais as implicações so ciais do resultado obtido para o setor rural e para a socieda de.

\subsection{Objetivos do trabalho}

A partir da análise dos objetivos explícitos do projeto fruticultura, este trabalho tem como preocupação estudar aspectos subjacentes ao atingimento de seus resultados. Através do projeto fruticultura, pretende-se estudar os aspectos relacionados à exploraçäo de novas alternativas no meio rural e, paralelamente, identificar as categorias de produtores envolvidas no projeto e as implicações sociais da exploração da nova alternativa fruticultura para as categorias de produtores e para a sociedade.

Pretende-se, então, especificamente:

a) verificar os resultados alcançados até o momento pelo projeto fruticultura, à luz de 
seus objetivos explícitos e da atividade-meio, ou seja o cultivo de ärvores frutife ras de clima temperado;

b) estudar os fatores relacionados à efetiva ६̧ão da fruticultura como atividade agrícola;

c) analisar algumas das consequéncias socioeco nómicas do projeto fruticultura para a sociedade e para o meio rural, identificando para que categorias de produtores o instru mento tem-se demonstrado funcional ou disfuncional;

d) caracterizar como as categorias de produto res agricolas, se inserem na sociedade inclusiva. 


\section{O PROJETO FRUTICULTURA}

o projeto fruticultura atinge basicamente a re gião sul do Paraná, onde as condições climáticas favorecem a exploração de frutas de clima temperado.

São beneficiadas pelo projeto as seguintes regiōes: Região Metropolitana de Curitiba, Palmeira, Porto Amazonas, Guarapuava, Maringá, Palmas, Litoral Paranaense e Colo nial de Irati.

Na Região de Iratí, especificamente, o proje to visa a introdução de novas variedades de frutas de clima temperado (maçã. pêssego, aneixa e nectarina\} como instrumento para alcançar os objetivos acima.

Considerando os altos custos de formação do po mar principalmente nos primeiros anos, está agregado ao proję 
to um programa de apoio financeiro à implantação da fruticultura. Nesse sentido podem ser destacado os recursos financei ros provenientes do crëdito rural e os recursos oriundos da aplicação de incentivos fiscais.

o Crédito Rural - o crédito aberto à fruticultura segue orientações da legislaçäo creditícia em vigor,com algumas normas de ajuste à natureza da atividade. Entre elas destacam-se: um período de carência, para reembolso das prí meiras parcelas financiadas, de até 3 anos: um prazo de paga mento de até 8 anos, incluindo o período de carência, äpoca de reembolso das parcelas coincidentes com época de colheita; teto das operações até 2000 vezes o maior valor de referência vigente no país (MVR). Vale ressaltar que a legislação em Vị gor não estipula limites mínimos para financiamento. Contudo, algumas agências financeiras têm adotado medidas nesse sentido. Em se tratando de investimento, as agências exigem planos técnicos que são elaborados pelo Serviço de Extensão Rural, o qual reserva a si o direito de cobrar uma taxa de assistência técnica. Assim, o Proponente do crédito comprome te-se a pagar $1 \%$ do valor financiado mais $1 \%$ a.a. sobre o saldo devedor, como taxa de assistência técnica.

Os valores financiados nunca poderão ser supe riores a $60 \%$ das garantias. Para cada crédito concedido é cobrado a taxa de juros em conformidade com os montantes de empréstimos concedidos:

$$
\text { até } 50 \text { MVR - } 13 \% \text { a.a. }
$$




$$
\begin{aligned}
& \text { de } 50 \text { a } 1000 \text { MVR - } 15 \% \text { a.a. } \\
& \text { de } 1000 \text { a } 2000 \text { MVR - 18\% a.a. }
\end{aligned}
$$

Incentivos Fiscais - A utilização de incenti vos fiscais na fruticultura é basicamente regulamentado pela Lei $n^{8} 5106$, de 02 de setembro de 1966, que dispõe "sobre os incentivos fiscais concedidos a empreendimentos florestais",e pelo Decreto-Lei 1134, de 16 de novembro de 1970, que atualmente se encontra alterada pelo Decreto-lei 1376 , de 12 de de zembro de 1974, que trata da criação de Fundo de Investimentos. A Lei 5106 estabelece, segundo o artigo $1^{\circ}$,que tanto as pessoas físicas quanto as jurídicas poderão descontar das declarações de rendimento, importâncias aplicadas em florestamento e reflorestamento. O parágrafo $1^{8}$ do mesmo artigo dispõe que "as pessoas fisicas poderão abater as importâncias comprovadamente aplicadas da renda bruta", enquanto - parágrafo $3^{\circ}$ determina que as pessoas jurídicas poderão deduzir 50\% do valor total do imposto de renda devido à União, uma vez comprovada a aplicação do montante, em "florestamento ou reflorestamento de essências florestais, ärvores frutiferas, ärvores de médio e grande porte". A mesma lei estabelece ainda, segundo a alínea $B$ do artigo $2^{\circ}$, um limite mínimo de plantio anual através de projeto aprovado pelo Ministério da Agricultura, de 10.000 árvores.

0 Decreto-Lei 1134 altera a sistemática de uti lização de incentivos fiscais para aplicação em "empreendimen tos florestais". Enquanto a Lei 5106 concedia direito de apli 
cação, de $50 \%$ do imposto de renda devido, tanto às pessoas físicas quanto às pessoas jurídicas, o Decreto-Lei 1134 se re fere apenas às pessoas jurídicas. Este estabelece, ainda,que as deduções sejam efetuadas antes da aprovação do projeto, en quanto que a Lei 5106 permite que se desconte valores somente através de planos previamente elaborados.

Com a promulgação do Decreto-Lei 1376, a legislação que regula a utilização de incentivos fiscais foi alterada, através da instituição dos Fundos de Investimentos. Entre eles o Fundo de Investimentos Setoriais (FISET), que, segundo o parágrafo único do artigo $2^{8}$ da mesma lei, "compreende três contas com escrituracões distintas: setor de turismo, pesca e reflorestamento". O setor de Reflorestamento, conforme o artigo $7^{\circ}$, tem suas contas operadas pelo Banco do Brasil S.A., sob a supervisão do Instituto Brasileiro de Desenvolvi mento Florestal - IBDF. A instituição do Fundo de Investimen to Setorial altera gradativamente, conforme o inciso IV do a $\underline{\underline{-}}$ tigo 1l, a parcela dedutível do imposto de renda aplicada em reflorestamento, mediante os seguintes percentuais:

$$
\begin{aligned}
\text { ano base } 1974 & -45 \% \\
1975 & -40 \% \\
1976 & -35 \% \\
1977 & -30 \% \\
1978 & \text { e seguintes }-25 \%
\end{aligned}
$$

Segundo Portaria Normativa $n^{8} 8$ do Instituto de Desenvolvimento Florestal, os empreendimentos florestais 
que visem recursos com base no Decreto Lei 1376 são definidos como: "Projetos Pröprios Fiset" e "Projetos Abertos Fiset" lou projetos de participação múltipla). A mesma Portaria estabelece ainda, segundo o artigo $13^{\circ}$, para os projetos de reflorestamento, que visem ao plantio de frutíferas, uma área míni ma de 50 ha contíguos.

\subsection{A viabilidade da atividade da Fruticultura}

Segundo as normas técnicas do Serviço de Exten são Rural, a fruticultura exige solos com "boa profundidade efetiva", bem drenado e fértil. o pomar pode ser instalado tanto em terrenos planos como em encostas de morro devendo-se contudo evitar os lugares baixos e úmidos. Verifica-se que o local de Iratí ajusta-se ao cultivo de frutas e que $2 / 3$ das terras são onduladas, dificultando, em parte, a mecanização de culturas agrícolas anuais. O fato do solo ser pobre não inviabiliza tecnicamente a atividade, uma vez que a baixa feI tilidade pode ser corrigida com fertilizantes químicos e orgâa nicos.

Climaticamente, pêssego, ameixa e maçã, respectị vamente, constituem as variedades que melhor se adaptam às condições da área, segundo observações realizadas pela Estaçào Experimental de florestal. A nectarina não tem demonstra do desenvolvimento vegetativo satisfatório, com frutificação de baixa qualidade. Em consonáncia com a própria recomenda- 
ção da Estação Experimental, os agricultores praticamente não a tem cultivado. As demais espécies, no entanto, já no segun do ano de produção, apresentam colheitas de excelentes qualidade, surpreendendo os produtores e os próprios técnicos locais. A produtividade tem superado as espectativas, como no caso de um produtor que obteve $5.700 \mathrm{~kg} / \mathrm{ha}$ de pêssego, quando se previa um rendimento de $3.500 \mathrm{~kg} / \mathrm{ha}$, segundo as Normas Técnicas.

Os sistemas de condução das frutíferas recomen dados pela pesquisa são orientados visando uma maior produção por unidade. Todavia, cabe ao produtor, através de suas obser vações e experiências, reajustar as formas de condução de acordo com: a localização do pomar, situação de microclima, fer tilidade do solo, produtividade, fenómenos climáticos adversos e outras questões de ordem técnica.

A atividade requer uma presença constante de mão-de-obra qualificada, que é obtida na unidade de produção familiar.

objetivamente a fruticultura tem se mostrado rentáve 1. Para o agricultor o rendimento parece assumir proporções maiores do que ocorre na realidade. Isto porque determinados fatores de produção não são remunerados, tais como a mão-de-obra e alguns insumos, como a matéria orgànica. Em algumas situações, ainda, os insumos são reduzidos ou até dis pensados pelo produtor. Se, porém, for levado em conta o cus to de produção do empreendimento, em conformidade com as Ta- 
belas 1,2 e 3 referentes à análise económica das culturas, verifica-se que a atividade apresenta retorno positivo somente após o quarto ano para a cultura de ameixa, a partir do terceiro ano para o pêssego e, após cinco anos para a maçã. Após oito anos, ressalvando os fenómenos de ordem climática, a produtividade das frutiferas tende a se manter, desde que o pomar seja conduzido adequadamente, em conformidade com as recomendações técnicas. São, portanto, culturas de retorno positivo a médio prazo, mas que exigem investimentos elevados.

\subsection{Perspectivas de mercado para a Fruticultura}

A análise de mercado demonstra uma melhor pers pectiva para a maçã. Até há pouco tempo a cultura da maçä era tida como inadequada às condições edafoclimáticas brasileiras e, assim, o produto existente no mercado era importado em sua totalidade. Recentemente, se obteve excelentes resultados com a cultura da maçã, principalmente no estado de Santa Catarina. Segundo $\operatorname{HENTSCKE~(S.D.)~o~País~possui~dois~mi-~}$ Ihões de hectares em condições tecnicamente adequadas à sua produção. No Paraná, as localidades de Palmas e Guarapuava reunem condições climáticas as mais favoráveis, por se situa rem abaixo do paralelo $23^{\circ} 20^{\prime} \mathrm{s}$, em pontos de maior altitude do Estado. Seguem-se os municipios de Castro, Ponta Grossa, Irati, Palmeira, Porto Amazonas, Rio Negro, Lapa, São Mateus do Sul, União da Vitória e Área Metropolitana de Curitiba, 


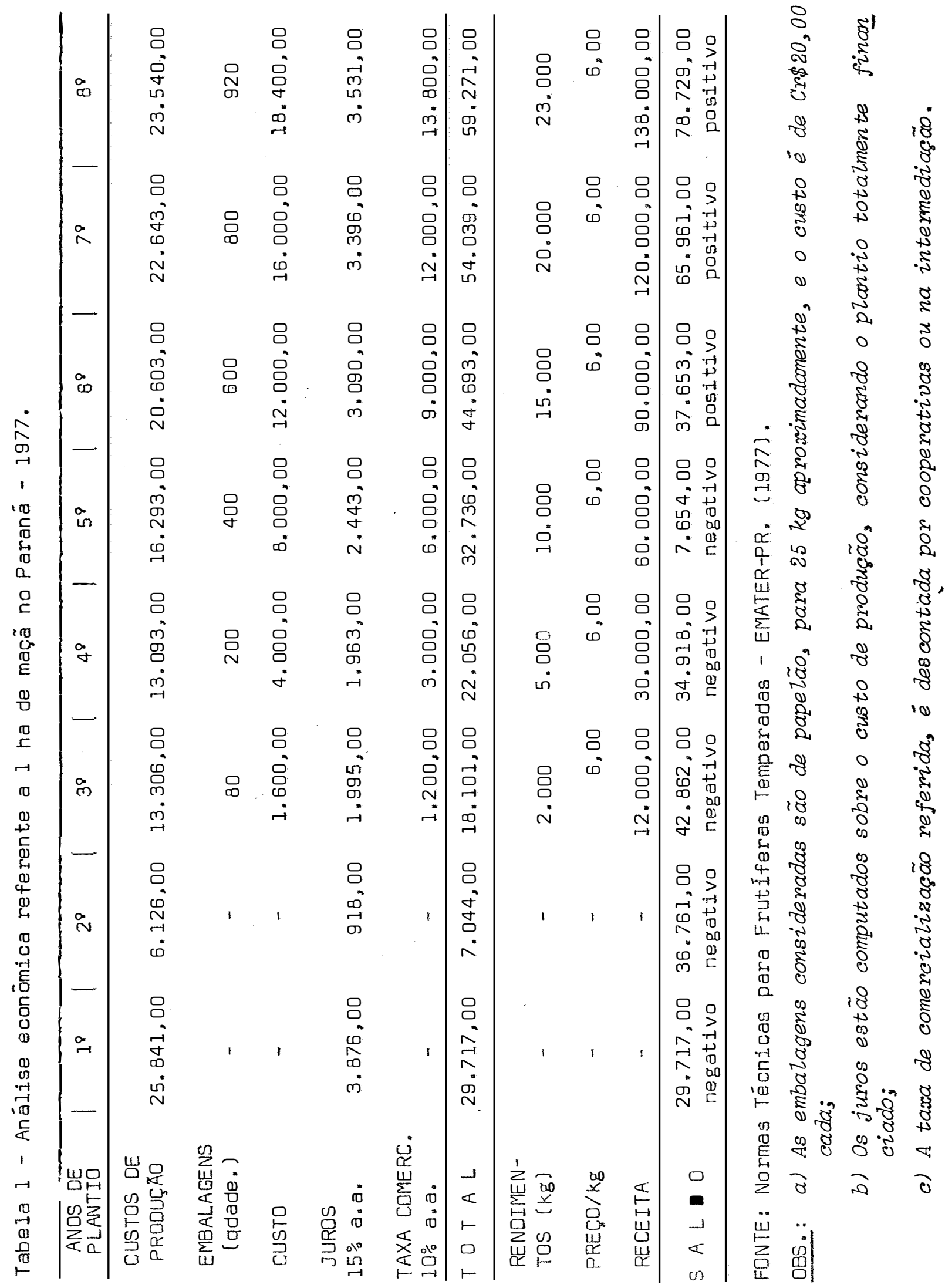




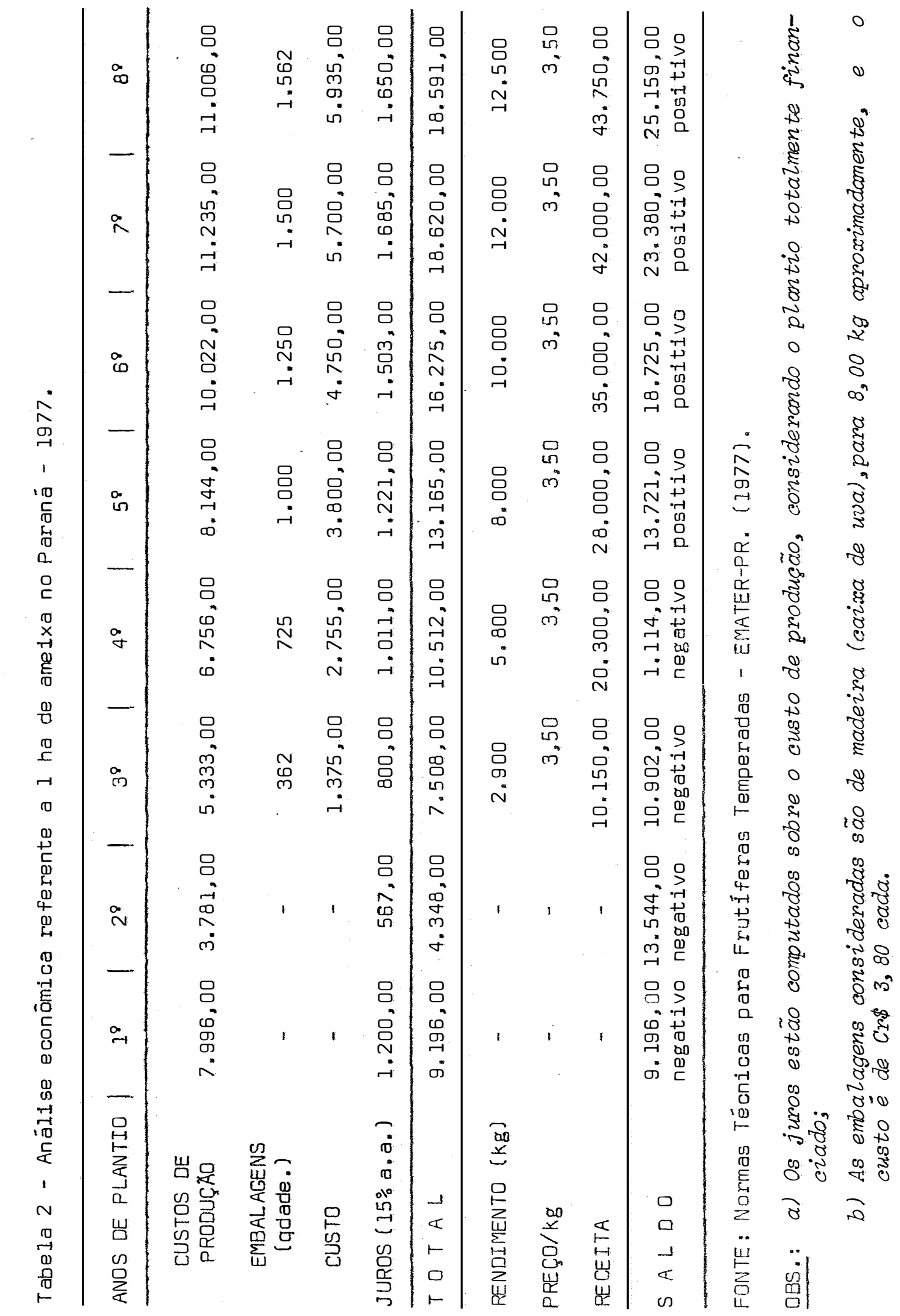




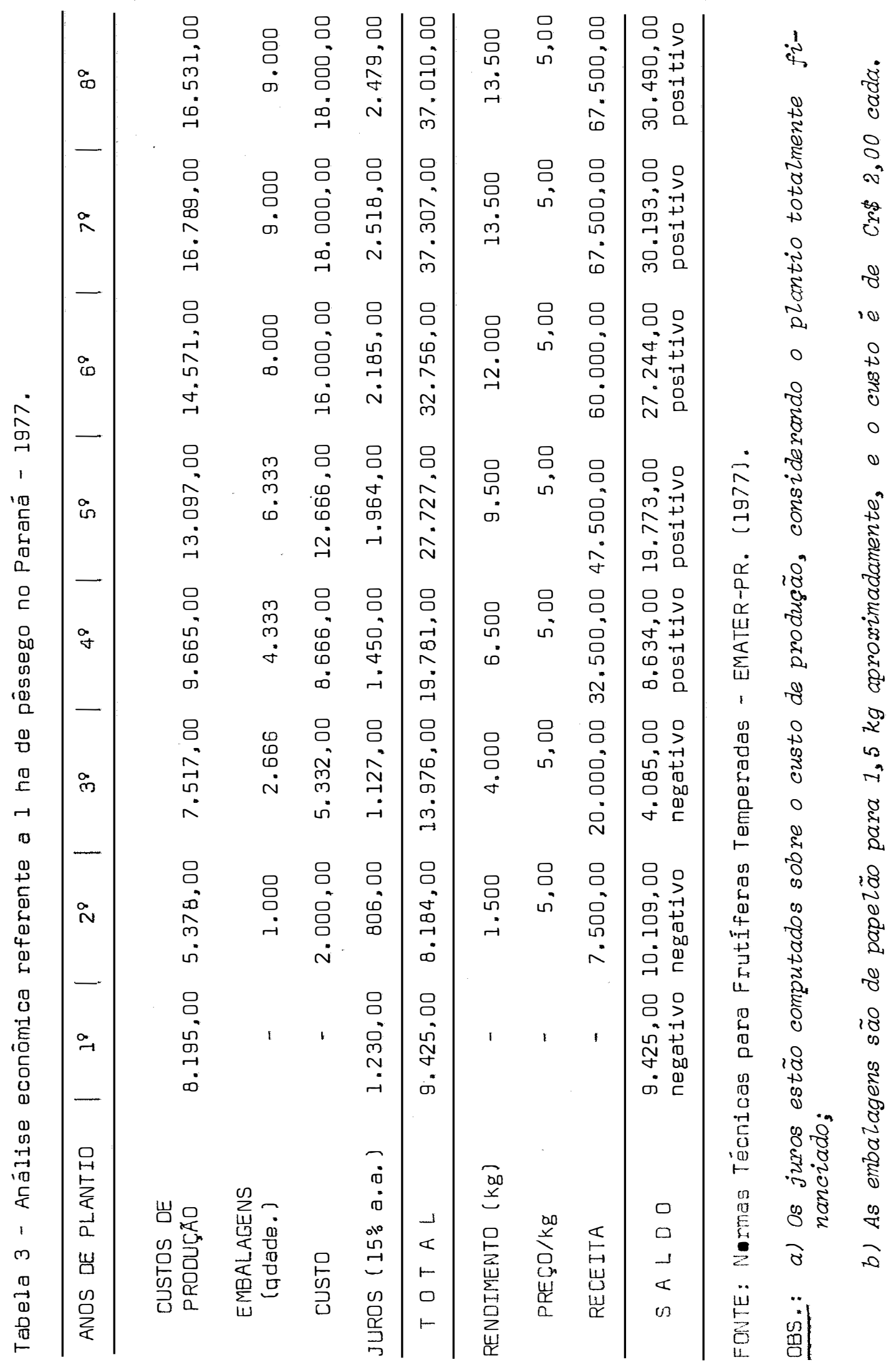


.18.

$($ ACARPA, 1975).

A importação da maçã nos dias atuais ainda é bastante significativa. Segundo dados da CACEX, em 1976, citado por HENTSCKE, (S.d.) "as importagões de peras e masãs custaram 122 milhões de dölares, representando $95 \%$ do valor total das importacões de frutas de clima temperado".

Uma análise na evolução das importações, conforme a Tabela 4, permite-nos melhor dimensionar as perspecti vas de mercado para a maçã.

De 1970 a 1975, o volume importado de maçã quadruplicou enquanto que a população cresceu em $59 \%$. Isto significa que o aumento do consumo da maçã não se deve apenas ao crescimento da população brasileira, mas a um maior consumo "per capita", que cresceu à razão de 6\% ao ano. D crescente aumento do volume importado da maçã, conforme a Tabela 4 , indica um déficit crescente na oferta nacional e um aumento na demanda desse produto.

Contudo, apenas o volume de frutas importadas não demonstra o potencial real do mercado para as frutíferas. Com a constatação de condições climáticas brasileiras adequa das ao desenvolvimento de espécies frutiferas temperadas, a ma çã principalmente começou a experimentar expansão da área cul tivada. Conforme mostra a Tabela 5, até l977, uma ärea de 9.000 ha era ocupada com essa cultura, representando uma produção estimada de 24.200 t. 
Tabela 4 - Maçã - Evolução de importações brasileiras.

\begin{tabular}{|c|c|c|c|c|}
\hline$A N O$ & $\begin{array}{c}\text { POPULAÇÃO } \\
\text { (1.000 HABITANTES })\end{array}$ & $\begin{array}{c}\text { VOLUME IM- } \\
\text { PORTAÇAO } \\
\text { (T) }\end{array}$ & $\begin{array}{l}\text { CONSUMO } \\
(\mathrm{kg} / \mathrm{Hab} .)\end{array}$ & $\begin{array}{c}\text { VALOR } \\
(\text { U } \$ 1000)\end{array}$ \\
\hline 1960 & 70.967 & 36.424 & 0,5 & 4.308 \\
\hline 1961 & 71.868 & 43.232 & 0,6 & 5.637 \\
\hline 1962 & 74.096 & 50.154 & 0,7 & 8.714 \\
\hline 1963 & 76.409 & 64.290 & 0,8 & 12.899 \\
\hline 1964 & 78.809 & 38.513 & 0,5 & 9.107 \\
\hline 1965 & 81.301 & 59.683 & 0,7 & 10.346 \\
\hline 1966 & 83.809 & 56.587 & 0,7 & 11.531 \\
\hline 1967 & 86.580 & 88.334 & 1,0 & 18.242 \\
\hline 1968 & 89.376 & 113.958 & 1,2 & 25.377 \\
\hline 1969 & 92.305 & 113.924 & 1,2 & 26.230 \\
\hline 1970 & 93.139 & 108.994 & 1,2 & 26.915 \\
\hline 1971 & 96.166 & 121.350 & 1,3 & 29.292 \\
\hline 1972 & 99.291 & 131.116 & 1,3 & 29.207 \\
\hline 1973 & 102.518 & 79.242 & 0,8 & 38.799 \\
\hline 1974 & 105.850 & 183.195 & 1,7 & 61.761 \\
\hline 1975 & 109.290 & 143.595 & 1,3 & 62.693 \\
\hline 1976 & 112.842 & 296.197 & 2,6 & 100.977 \\
\hline
\end{tabular}

FONTE : CIEF - FIBGE (Citado por HENTSCKE, S.d.). 
Tabela 5 - Situação da cultura da maçã nos estados do Sul do Brasil - 1977 .

\begin{tabular}{cccc}
\hline Es t a dos & $\begin{array}{c}\text { Area } \\
\text { ocupada } \\
\text { (1977) }\end{array}$ & $\begin{array}{c}\text { Estimativa de } \\
\text { produça } \\
1976 / 1977\end{array}$ \\
\hline São Paulo. . . . . . . . & 1.500 & 8.900 \\
Paraná. . . . . . . . . & 1.000 & 1.500 \\
Santa Catarina. . . . . . & 5.000 & 12.300 \\
Rio Grande do Sul. . . . & 1.500 & 1.500 \\
\hline
\end{tabular}

FONTE: HENTSCKE (S.d.).

Se for acrescentado ao volume importado de maçã em 1976, a estimativa da produção nacional na safra 1976/77. obtém-se um montante de 310.397 toneladas. Este número, por outro lado, revela um consumo "per capita" de $2,7 \mathrm{~kg}$. É interessante observar que do montante consumido apenas $7 \%$ é pro veniente da produção nacional.

HENTSCKE (s.d.), previu para 1985/86 uma demanda de 475.000 toneladas, considerando um consumo "per cap $\underline{i}$ ta" de $3,34 \mathrm{~kg}$ e uma população de 142 milhöes. Levando em con ta que nesse mesmo ano seria obtido com a mesma área 150.000 t.. a produção nacional supriria apenas $31 \%$ das necessidades. Mas, considerando-se um aumento de 9.000 ha até 1980 (correspon dentes a 3.000 ha anuais: 1978, 1979, 1980), B Brasil atingiría em 1985/86 uma produção de 240.000 t., ou seja, $50 \%$ da deman- 
da estimada.

Embora o déficit de produção tenda a diminuir, com o aumento da produção nacional, em 1985 ainda terá que se importar 235.000 toneladas para atender as necessidades de consumo. Se a meta for a autosuficiência, para um rendimento 23.000 kg/ha, (conforme a Tabela l), infere-se que, além da expansão da cultura já prevista, dever-se-á cultivar mais 10.200 ha de maçã.

Tabela 6 - Comercialização de frutas no CEAGESP em 1975 - Pe $\underline{\mathbf{r}}$ centual em função da origem.

\begin{tabular}{lcc}
\hline Produtos & Importado & Nacional \\
\hline Maçã & $89,4 \%$ & $10,6 \%$ \\
Pera & $90,0 \%$ & $10,0 \%$ \\
Péssego & $3,8 \%$ & $96,2 \%$ \\
Nectarina & $2,0 \%$ & $98,0 \%$ \\
Ameixa & $22,4 \%$ & $77,6 \%$ \\
\hline
\end{tabular}

FONTE: HENTSCKE (s.d.).

A Tabela 6 mostra que $77,6 \%$ da ameixa comercializada no CEAGESP, é procedente de produção nacional, e que, para as espécies aquí consideradas, as perspectivas de mercado estariam favorecendo à maçã em primeiro lugar, seguida da ameixa e do pẽssego, respectivamente.

As colocações anteriores demonstram a viabilidade do projeto através dos aspectos técnicos e económicos da atividade fruticultura e mediante as boas perspectivas de comercialização principalmente para a maçã. Resta verificar,a partir dos resultados obtidos, os beneficios decorrentes desta prática para as várias categorias de produtores. 
.22 .

\title{
3. ORIENTAÇÃO TEÓRICO-METODOLOGICA
}

\subsection{Revisão de Literatura}

\author{
Os estudos relacionados à adoção de novas prá- \\ ticas na agricultura têm sido realizados à luz das teorias de \\ adoção de inovação. Entre os teóricos de adoção ROGERS (1962, \\ 1971), pode ser considerado como um dos mais preeminentes. Sua \\ teoria procura explicar a adoção de novas práticas através de \\ atributos da própria prática ou da atitude dos agricultores \\ frente a ela. Esta perspectiva analitica concentra-se mais \\ nas características psicospciais do individuo, em detrimento \\ da análise da relação do indivíduo com o sistema social, do \\ qual é integrante e, portanto, das situações e condicionantes, \\ sob os quais age o agricultor.

$$
\text { Pelo seu carāter restritivo a teoria de ROGERS }
$$


vem sofrendo críticas dos estudiosos de adoção de inovação, entre os quais podem-se destacar: SOUZA (1974), MUNIZ (1974), BURKE E MOLINA (1976), MARTINS (1975), GALJART (1976), SAMANIEGO (1971), entre outros.

PATRICK (1975) resume a duas as correntes de pensamentos que oferecem explicações para a permanència de práticas tradicionais de produção e, consequentemente, do atra so do meio rural. A primeira postula a existência de uma subcultura que é transmitida de geração a geração pelo processo de socialização e que faz com que os grupos, através do seu sistema de vida, respondam negativamente ás inovações. A segunda tem em conta que as atitudes de manutenção de padrões constituem uma decorrência dos fatores situacionais.

A permanência de um sistema tradicional de pro dução agrícola ou de uma subcultura, que resiste a padrães de valores, que propulsionam a expansão de uma nova ordem de integração societária, é atribuỉda em muitos estudos, no Brasil, ao atraso do meio rural. Estes estudos analisam as ques tões relacionadas ao atraso, num vácuo estrutural, sem situá- los no contexto da realidade social mais ampla.

SAMANIEGO (1971) mostra que os programas de ex tensão rural na América Latina, fundamentados na teoria que relaciona os obstáculos de adoção de novas técnicas de produ ção à cultura camponesa, por não considerar certas formas de produção pré-capitalistas, bem como as condições estruturais em que ocorre o processo de produção agrícola, ap resentam efei 
tos discriminatórios e tendeni a favorecer as categorias sociais socioeconcmicamente privilegiadas.

Embora muitos cientistas sociais tenham persis tido na abordagem, que aponta como explicativo para a resis têncla às inovações a atitude tradicionalista, a ignorância e o localismo, outros acrescentaram variáveis que não exclusivamente as culturais ou psicossociais. Entre eles, um sociólogo holandes em pesquise no Brasil, concluiu que os conceitos "modernos e tradicional" têm sido insuficientes para explicar o problema de desenvolvimento (GALJART, 1976). Obser va ele que o desenvolvimento agrícola não é impedido em consequência de atitudes contrárias ao processo de mudança ou à modernização da agricuitura, mas pela falta de organização dos produtores agrícolas, bem como pelas condiçães de uso de terra, e pela falta de recursos da maioria dos agricultores para comprar tecnologia. São fatores situacionais ou estruturais que são contemplados em sua análise. Em sua perspectiva, três ordens de fatores poderiam ser considerados como entraves ao desenvolvimento agrícola: a "ignorância", a "impotência" e a "não disposifão". Com esses três conceitos. GALJART (1976) parece dar nova conotação ao conceito "moderno". Ser moderno é ter capacidade de "reflexão critica sobre cada ą̧ão e instituigão no sentido de se avaliar se os objetí vos não poderiam ser obtidos de outra maneira. A capacidade de reflexão e, consequentemente, da concretizasão da aq ão estaria relacionado ao conhecimento, ao interesse e à possibili 


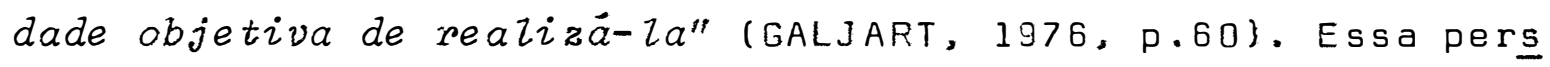
pectiva, sem dúvida, vem redimensionar a postura analítica, abrindo novos caminhos de interpretação heurística. Contudo, - autor não explora analiticamente o processo de articulação entre os conceitos.

Ainda no que se refere aos teóricos da adoção de novas práticas agrícolas, PAIVA (197l) conclui que a expansão de novas técnicas na agricultura não pode ser vista somente no ámbito do setor rural, pois ela depende do desenvolvimento do "setor não agricola". Também. MARTINS(1975), ao estudar a modernização e o problema agropecuário no estado de São Paulo, mostra que o atraso agropecuário e o progresso urbano-industrial não se explicam separadamente, mas constituem um todo articulado.

A adoção de inovações na agricultura foi estudada sob o enfoque da teoria da Ação Social por MUNIZ (1974) e SouzA (1974). Nela, a inovação é considerada como um meio para atingir fins ou metas, definidos pelo produtor. A utilização de uma inovação pelo produtor é resultante de uma refle xão,pela qual são contemplados elementos componentes da situa ção, em que desenvolve sua atividade. Constitue uma análise relacional produtor-situação.

A partir das pesquisas já realizadas, entende- se que o estudo sociológico de novas práticas agrícolas não pode restringir-se em torno da análise individual do produtor e nem, tampouco, limitar-se a una análise de caráter global, 
que considere apenas os chamados aspectos estruturais, ou con dicionantes situacionais, em que o produtor opera. Como com ponente de uma categoria social e como ser histórico-social que é, o agricultor reflete experiências proporcionadas pelo meio em que vivencia e já vivenciou. Neste sentido, ele age não apenas em função de uma realidade presente, mas, também, em função de experiências passadas. Suas ações não são desen volvidas mecanicamente, mas inspiradas em sua tradição de vida, suas crenças, seus ideais e sentimentos, que fazem parte do meio em que vive. Também, a análise do produtor e dos elementos que manipula em seu meio näo pode estar desvinculada da ordem social mais ampla, uma vez que o meio rural reflete aspectos da sociedade global, da qual é integrante. Com esta postura analítica busca-se elementos teóricos para orien tar o presente estudo. Eles serão, pois, desenvolvidos no próximo segmento.

\subsection{Orientação teōrica}

Já distanciado de suas raízes, ou da analogia simplista entre o organismo e a sociedade, o método de inter pretação funcionalista representa um dos diversos instrumentos capazes de sistematizar logicamente a apreensão de elemen tos da realidade objetiva, sob o ponto de vista sociológico. Entre os teóríos do funcionalismo, Robert $K$. Merton merece destaque como sistematizador e como revisor crí 
tico da teoria. Sua orientação, no exame das concepções da interpretação funcional no ámbito das premissas lógicas, reme te a três postulados, os quais, segundo sua análise, foram desenvolvidos pelos funcionalistas. São eles: "O Postulado da Unidade Funcional da Sociedade"; "O Postulado do Funcionalismo Universal" e "O Postulado da Indispensabilidade".

Partindo, em sua análise, de perspectivas ado tadas pelos clássicos do funcionalismo, tais como Malinowski e Radcliffe Brown, MERTON (1970) chega a conclusões de relevante importància para a "codificą̧ão" da análise funcional. Sua sensibilidade para com os problemas de natureza metodológica na sociologia o fez perceber a "excessiva penalidade intelectual" que se pagava pela simples transferéncia de conclü söes antropológicas, obtidas nas esferas das sociedades iletradas, para as sociedades mais complexas. Sua perspicácia cientifica faz subordinar a discussão do método de interpreta ção funcionalista aos "cânones" da lógica da ciência experimental.

Sem considerar, no entanto, esgotada a solução para os problemas da análise funcional, sua revisão teóri ca o leva a elaborar um "Paradigma da Anälise Funcional na So ciologia", cujo conteúdo, segundo suas palavras, "não representa um conjunto de categorias introduzido de novo, mas sim uma codificasão daqueles conceitos e problemas que têm sido impostos à sua atengão"... (MERTON: 1970, p.117).

o "Paradigma" de Merton orientará este traba- 
Iho, através de alguns elementos conceituais básicos para a análise.

A teoria desenvolvida por Talcot Parsons também tem contribuições significativas. Representa um avanço, no que tange às teorias de maior amplitude de interpretação na sociologia. O referencial básico é a ação social, desenvolvida a partir de uma revisão crítica das contribuiçōes de Durkheim. Marshall, Pareto e Weber. Ela será utilizada para desenvolver o conceito de sistema social e seus componentes. Segundo a orientação de Parsons, "a sociedade não pode ser tomada simplesmente como um sistema social, mas sim como um complexo de subsistemas interdependentes: (PARSONS: 1975,0.50). Assim, o sistema social, considerado no presente estudo, situa-se a nível de grupos ou categorias sociais que se articulam entre si. É evidente que, quando é relacionada uma ou ou tra categoria com a sociedade, ocorre uma articulação com os seus subsistemas.

Tem-se o sistema das categorias rurais como uma pluralidade de atores individuais, interagindo numa dada situação. "Reduzido aos seus termos mais simples, um sistema social, consiste numa pluralidade de atores individuais inte ragindo numa situagão que tem pelo menos um aspecto fisico ou ambiental. Os atores são motivados relativamente a uma tendência de obter o máximo de satisfąões, e a reląão de cada qual com sua situacão e com os outros é definida e mediatizada por sistema comum de simbolos culturalmente elaborados" 
(PARSONS: 1975, P.58).

Considerando a colocação de $\operatorname{MERTON}(1970$, p.118): "em qualquer circunstância, a anälise funcional admite ou ope ra, explicitamente, com alguma concepção de motivação e que tal conceito de natureza subjetiva tem sido fundido erroneamente com categorias objetivas". Com Parsons 3 sta fusão adqui re um caráter de interpretação, através da concepção de sistema de ação social constituído, analiticamente, pelos siste mas orgánico de personalidade, cultural e social. Embora a motivação possa afetar conceitos de função subjetiva, na versão Parsoniana, constitui um componente da ação conceitualmen te encarado numa perspectiva relacional, isto é, advindo de uma relação ator-situação.

A decomposição dos componentes do sistema social, mediante um esquema relacional ator-situação, coloca näo o ator individual como unidade básica de análise, mas o processo de interação entre os atores no desempenho de seus papéis. Segundo PARSONS (1975), abstraindo-se o papel de um ator do sistema total de sua personalidade torna-se possível analisar a articulação de sua personalidade com a organização do sistema social.

Complementando a orientação analítica de Merton, a contribuição de parsons confere, pois, ao sistema teórico de referência uma amplitude analitica, cujos conceitos, acredita-se, sejam capazes de apreender,objetivamente, os diversos elementos relacionados a novas práticas agrícolas num 
sistema social em mudança.

\section{3. o projeto Fruticultura como objeto de análise}

A Fruticultura é analisada no presente estudo, sob duas dimensöes: como projeto e como atividade. Como projeto é entendida como um instrumento de intervenção da sociedade, orientado ao setor agrícola com propósitos definidos em torno do aumento de produção, da redução de importação e da fixação do pessoal ao seu meio. Como atividade, se defini có mo uma nova IInha de exploração proposta ao produtor, como objeto-meio, constituinte de uma dada situação rural.

Dois níveis de anälise são, pois, distingüídos no presente estudo: O primeiro situa-se no plano dos obję tivos explícitos da fruticultura como projeto; o segundo refe re-se às conseqüências implícitas do projeto, isto é, da fru ticultura, como atividade da unidade de produção agrícola. Es ta distinção é baseada nos conceitos "Função Manifesta" e "Fun cão Latente", que respectivamente se referem: a) aos propósitos intencionados de um objeto, levando um grupo ou sistema social a um ajustamento; b) a conseqüências não intencionadas de um fato ou objeto social para um sistema social(MERTON, $1970\}$

o setor rural é concebido como um sistema social, que, por sua vez, articula-se em termos politicos, culturais, sociais e económicos com o sistema social inclusivo, 
isto é, com a sociedade como um todo. Entende-se "o rural" como um subsistema inserido na sociedade.

Deve-se ressaltar a distinção que se faz entre - conteüdo do conceito "insergão" e de "integragão". Integra çäo expressa a unidade de um sistema vital em seu todo, onde seus subsistemas ou partes interrelacionados congruentemente contribuem e beneficiam-se mutualmente na dinàmica dos processos. Nesta perspectiva, um subsistema pertencente a um sistema assim caracterizado encontra-se "ajustado". 0 conceito de inserçäo se distingue por transmitir a noçäo de conexão entre os subsistemas podendo ser entendido como graus de inte gração, ou integração parcial. Nesse sentido, MERTON (1970: p.102) também, considera que "... não se pode admitir a completa integração de todas as sociedades, mas que esta $\ddot{e}$ uma questão de fato, empirica, na qual devemos estar preparados a encontrar uma escala de graus de integracão".

Distingue-se o setor rural como um sistema social, cuja realidade é expressa em termos de grupos, ou categorias sociais. O maior ou menor grau de integração se define na medida que as categorias participam de uma ordem económica capitalista, que tem por base a economia de mercado. A sociedade atinge sua plenitude, em seu processo de desenvolvimento, quando os subsistemas estiverem, não apenas interrelacionados, mas, também integrados, mediante uma economia de mercado onde as relações de troca tendem a favorecé-los. A sociedade estará, então, ajustada mediante subsis- 
temas interdependentes.

A interrelação social do setor rural com o sis tema mais amplo é efetuada através dos grupos sociais, sendo, porém, que determinados grupos poderão estar mais interrelacionados do que outros, ou até integrados.

A concepção de sistema de ação de Parsons envolve, intrinsicamente, um conceito de racionalidade no senti do de que os atores são movidos em busca de fins ou interesses, visando maximizar gratificações e evitar privações.

Quatro subsistemas são básicos na conceituação analítica da ação humana, na perspectiva de Parson: o sub sistema orgánico, subsistema de personalidade, o subsistema cultural e o subsistema social. Cada subsistema deve ser con siderado independentemente quanto a sous elementos organizacionais em termos analíticos, embora se interpretem e se interrelacionem.

A situação em que se desenvolve a ação é definida como consistindo de objetos sociais e não sociais, em re lação aos quais os atores se orientam diferentemente e em con formidade com a natureza dos objetos. Nessa perspectiva, os vários objetos constituintes situacionais são caracterizados em: culturais, sociais e empíricos.

Os objetos sociais são representados pelos atọ res individuais e coletivos. Nesse sentido cada individuo é um ator, objeto de orientação, tanto para si como para os ou- 
tros atores. Também um grupo ou categoria de atores pode ser tomado como unidade de referéncia. Atores, que participam de situações com determinadas características em comum, denominam-se grupos ou categorias sociais. Tais categorias, à medi da que se articulam entre si e com outras que extravasam o se tor rural, projetam-se num mundo de orientação e influência de origem externa, conferindo um caráter dinâmico à natureza dos componentes do sistema de orientação da ação.

Os objetos culturais são as crenças,idéias, pạ drões de valor e elementos simbólicos da tradição cultural. Os elementos culturais tendem a oferecer maior estabilidade ao interior do sistema de ação, entendendo-se, porëm, que não permanecem estáticos.

Os objetos empíricos representam elementos cons tituintes da situação que não interagem com os atores, embora possam influenciar as ações. Constituem os "meios" (elementos que os atores utilizam na consecução das metas) e as "con dicões" objetivas (elementos fora de controle do ator), que podem limitar ou favorecer seus objetivos. Os elementos fora de controle do ator são aqui denominados "condicionantes da acãa". Tais aspectos adquirem expressão analítica no presente trabalho, de vez que a fruticultura constitui um dos objetos meios, que tem por meta proporcionar uma gratificação "eco nômica" às diversas categorias e, nesse sentido, supõe-se, de acordo com seu projeto, ser uma tecnologia socialmente adequa da. A preocupação converge para a constatação objetiva do fa 
to, bem como para a apreensão dos elementos que estão relacio nados à sua efetivação como atividade agrícola. Procura-se de tectar dessa maneira, a nível das categorias rurais,os elemen tos que condicionam a utilização da fruticultura, como também os aspectos de orientação da ação, que levam-na a reagir positiva ou negativamente em relação ao objeto-meio.

o ambiente empírico em que se desenvolve a ação que será analisada é representado por uma situação constituída cie objetos, entre os quais destacam-se: tamanho da proprie dade da terra, ou da unidade produtiva, os meios de transporte, a estrutura de comercialização, o preço do produto, o cré dito agrícola, os quais assim definidos poderão favorecer ou limitar a utilização do objeto. E ainda contemplado com obje tos-meios, os quais constituem as demais "alternativas", que poderão gratificar o ator em maior ou menor grau, de acordo com seus interesses, definidos à luz da estrutura de sua personalidade. Esses objetos-meios são as demais explorações, instrumentos e práticas agrícolas.

Na relação ator-situação ressalta-se a motiva ção para a ação. Ela é subjetiva e move o ator em busca de metas, definidos em consonância com padrões culturais. Deve-se entender que a energia motivacional, que impulsiona o ator, processa-se no sistema ator-situação e, embora seja subjetiva e tenha suas origens no organismo do indivíduo, não de ve ser considerada simplesmente como uma energia que busca o atendimento da "necessidade básica do organismo". Antes, a or 
ganização dos elementos da ação constituem uma "disposição pa ra a ação", cujo produto advem da sua relação com os elementos constituintes da situação.

A organização da ação é efetuada com base nos elementos orientadores da ação, que podem ser de ordem motiva cional e de valor. Estão contemplados não somente aqueles ele mentos que o ator percebe na realidade presente, mas, também os elementos frutos da experiência de sua relação com a situação. Assim, a não utilização de determinados meios pode ter relação com a não obtenção de gratificação, ocorrida em experiéncias passadas.

Para cada ação que se organiza, estrutura-se um sistema de expectativas que vai definir o grau de realiza ção do ator. Assim, com a utilização de um objeto-meio espe ra-se atingir a meta definida previamente. Por exemplo,em tor no do objeto fruticultura desenvolve-se expectativas tais como: melhorar o rendimento económico, assegurar um limite de renda, etc...

Com relação aos objetos-meios, a ação que se desenvolve na situação é orientada pelos tais objetos, sendo que as propriedades dos objetos, bem como o produto de sua utilização, constituem elementos contemplados num balanço critico que é efetuado pelo ator, visando maximizar gratifica ções. O resultado desse balanço, em função de suas expectati vas, o fará optar por uma das alternativas da situação.

No que se refere aos elementos de orientação 
motivacional, três aspectos se manifestam nesse processo:

- o aspecto cognitivo: diz respeito à forma como o ator percebe um objeto em relação a seu sistema disposição-necessidade;

- o aspecto catético: diz respeito a um envolvimento de caräter emocional com o objeto;

- o aspecto avaliativo: relaciona-se com o envolvimento de orientações de objetos anteriores, num esforço de otimizar gratificações, recaindo num dos objetos-meio da ação (PARSONS: I968, p.81\}.

Em estreita relação com a orientação motivacio nal, a orientação de valor submete o ator a marcos ou padrões normativos num processo de escolha. Constituem elementos normativos os padrões cognitivos, estético e moral. A distinção dos vários aspectos do processo de orientação da ação é efetuada apenas para fins analíticos, o que não quer dizer que num processo real de ação tais elementos categorizados se desenvolvam distintamente nas diferentes etapas da ação.

A reação positiva ou negativa em relação à utí lização de um objeto-meioé, pois, definido em função de padrões regulados culturalmente e em função de elementos de orientação, que se situam no àmbito de controle ou não do ator. Tem-se, então que, a não utilização de um objeto-meio pode es tar relacionada aos elementos subjetivos da ação ou aos condi 
cionantes empíricos da situação, em que se desenvolve a ação. Isto porque os atores possuem consciência dos objetos situacionais, em função do que eles percebem e dos seus interesses ou metas.

Considerando a relação ator-objeto, PARSONS co loca que o envolvimento do ator com qualquer objeto o submete a dilemas aos quais deve apresentar respostas. Estas respos tas dizem respeito à opção por determinados padrões de orien tação que constituem "variáveis padrões" de ação (Pattern Variables):

1) "Universalismo-particularismo": D ator opta pelo universalismo se, ao avaliar um objeto, adota os mesmos critérios para julgar um conjunto de objetos; ou, ao contrário, opta pelo particularismo se, avalia com critérios inerentes ao objeto.

2) "Desempenho-qualidade": O ator avalia um objeto pelo que ele produz, istoé, pelo seu desempenho; ou, inversamente, pelo que ele é, pela sua qualidade, independente de seus resultados.

3) "Afetividade-neutralidade afetiva": 0 ator pode referir-se a um objeto de forma afetiva, como, também, pode renunciar a afetividade. 
.38.

4) "Especificidade-difusão": As relações do ator podem ter um caräter específico, de cu nho profissional, por exemplo, ou abranger aspectos gerais ou difusos.

Levando em conta o objetivo de integrar as categorias sociais no processo de desenvolvimento, a fruticultu ra somente é considerada relevante quando houver uma disposi ção por parte do ator em explorá-la visando o mercado. A releváncia refere-se a uma decisão favorável à prática da fruti cultura com vistas à busca de valores monetários. Assim, para que a fruticultura atinja seu objetivo, por um lado, deve haver subjetivamente uma prédisposição do ator para a utiliza ção do objeto, por outro, para que o ator seja gratificado economicamente, os condicionantes situacionais devem estar ajustados à obtençäo dessa gratificação.

Diferindo as características situacionais do sistema de ação dos atores aqui categorizados, a alternativa fruticultura tanto pode proporcionar a gratificação esperada como näo, e, nesse sentido, demonstrar-se funcional ou disfun cional para determinada categoria, como também funcional ou disfuncional para a sociedade.

"A especificąão das unidades, para as quais seja funcional um elemento social ou cultural, deve ser exi gência expressa de una estrutura teórica de anälise funcional. Ela deve conceber que um determinado elemento tenha di- 
versas consequências, funcionais e disfuncionais, para individuos, para subgrupos e para a estrutura e cultura social mais ampla" MERTON (1970: p.96-97).

o objeto demonstrar-se-á funcional à medida que sua efetivação como atividade propiciar um ajustamento do ator na situação e no àmbito da economia global, e disfuncio nal quando isto não se der ou fizer diminuir seu ajustamento MERTON (1970).

0 ajuste que o instrumento visa proporcionar, tendo por base a economia de mercado, diz respeito a uma gratificação, sobretudo mas não exclusivamente, económica e monetária. Usando a fruticultura, deve haver necessariamente gra tificação económica, condição para participação em um mercado de troca, cujo elemento mediador é o dinheiro. Assim, quanto maior a gratificação económica, proporcionada pelo objeto, maior a possibilidade dos que dele se utilizam de se ajustar à nova ordem de integração societária e maior a possibilidade de aquisição de bens e serviços, que têm origem externa ao setor rural. Então, a fruticultura demonstrar-se-á:

Funcional, quando se apresentar como relevante na situação e os elementos condicio nantes da ação permitirem ao ator com sua utilização, como objeto meio, obter uma gratificação económica;

Disfuncional, quando se apresentar como relevante na situação e os elementos condicionantes da ação pri- 
varem o ator, com a sua utilização como objeto-meio, de obter uma gratificação econōmica.

Deve ficar claro que a não utilização da frutí cultura pode estar relacionada à preservação da unidade vital do sistema, através de seus componentes, ou mediante a gratificação de caráter não econômico. Mas tal subsistema não está ajustado na perspectiva da sociedade, pois esta necessita de produtos para a alimentação de uma população não engajada na produção de alimentos, como também necessita vender os pro dutos ai fabricados. Nestas condições, o objeto pode predis por o ator ao seu uso, porēm a não efetivação da ação poderá ser produto de uma racionalização, no qual estariam contempla dos elementos empíricos, condicionantes, que limitariam o ator de obter a gratificação de acordo com sua expectativa. Tem-se, neste caso, uma condição de relevância do objeto, porém, uma limitação para usà-lo. o objeto pode também nāo motivar o ator, pois este pode não encontrar naquele as propriedades que pos sam gratificá-lo. Desse modo, tem-se uma condição de irrelevància do objeto.

Os casos de irrelevāncia do objeto, implicam num conceito de afuncionalidade, ou seja, o objeto-meio demonstra-se afuncional na situação.

Os diferentes resultados que podem ser obtidos com a atividade fruticultura estão relacionados com as diferentes funções que o subsistema da categoria de produtor assu 
.41 . me na sua inserção no sistema social inclusivo.

Para que o sistema de ação do produtor se mantenha equilibrado neste sistema maior, certas necessidades ou requisitos de ordem interna e externa devem ser satisfeitos. Parsons destaca que em um sistema social quatro requisitos ou funções bäsicas devem ser preenchidas. Este conjunto de fun ções é conhecido pela sua forma abreviada A G I L.

1) Adaptativo: refere-se a adaptação do siste ma às condições genéricas da situação. Realiza-se pelas ações que buscam recursos, es tabelecendo relações com o meio exterior e proporcionando a troca de produtos.

2) Consecução de objetivos: relaciona-se com a definição de objetivos, com os interesses do sistema e com os meios utilizados na con secução das metas.

3) Integração: refere-se às ações que controlam o sistema evitando desvios em excessos. Asseguram ao sistema consisténcia e continuidade.

4) Latência: refere-se as ações acumuladas de energia que proporcionam a motivação para a busca de metas. As ações mantém estreitas relações com padrões culturais.

As quatro funções do sistema tem, respectivamen te, relação com os subsistemas da ação: o subsistema orgànico ou biológico, o sub-sistema de personalidade, o subsistema so cial e o subsistema cultural. Isto quer dizer então que o 
sistema geral da ação em sua dimensão externa, tem o subsistema orgánico organizado através de seus elementos, envolven do o organismo comportamental em torno da adaptação aos compo nentes do meio ambiente, e o subsistema de personalidade em torno da consecução dos objetivos ou metas. Em sua dimensão interna, o sistema de ação tem o subsistema cultural organiza do em torno dos padrões de manutenção e o subsistema social em torno da integração das unidades de ação, entendidas como personalidades comprometidas em papéis.

\subsection{Aspectos operacionais}

A especificação de variáveis analíticas, após a definição do sistema teórico de pesquisa, visa melhor delimi tar o processo de investigação. Esta orientação permitiu que se testasse um esquema operacional fundamentado em uma escala de mensuração de "Padröes de orientafão do Produtor". Esta es cala tinha como princípio que os padrões de orientação de caráter instrumental ou moderno estariam diretamente relaciona dos com o maior grau de exploração da nova alternativa fruticultura. Inversamente, um padrão de orientação tradicional ou expressivo estaria diretamente relacionado com um menor grau de plantio de frutiferas.

Submetida ao teste, a escala mostrou-se inadequada para este trabalho. Isto porque, de acordo com o que preconiza a técnica, a sua aplicação deve ser padronizada. És 
ta orientação fazia com que se obtivessem respostas induzidas deixando dúvidas quanto ao real posicionamento do entrevistado.

Concluiu-se ainda que, em razão do caráter sistémico da abordagem Parsoniana, a fixação prévia de algumas variáveis analiticas viria empobrecer substancialmente o potencial analitico que os conceitos oferecem. Verificou-se, então, que a reconstrução analítica da realidade empírica, tendo como fulcro o modelo AGIL, demonstrar-se-ia mais apropriado. Explorou-se as dimensões funcionais do sistema social apreendendo as orientações ou ações que procuram satisfä zer as necessidades do sistema, na perspectiva do produtor. Embora as quatro funções orientem a análise, é basicamente a partir da função integração que se procura entender o sistema rural.

A anälise trata dos aspectos subjacentes ao Projeto fruticultura e nesse sentido situa-se no ámbito dos pro dutores, que operam em unidades produtivas com característi cas semelhantes (categoria de produtores). Não se trata da re construção ampla do sistema social rural. Procura-se entender sob que forma os produtores, através de seu papel, se articulam com a sociedade e, em segundo lugar, o que significa a nova alternativa para o sistema de ação desses produtores.

Segue esquema de conceitos básicos para a operacionalização do estudo. 
.44.

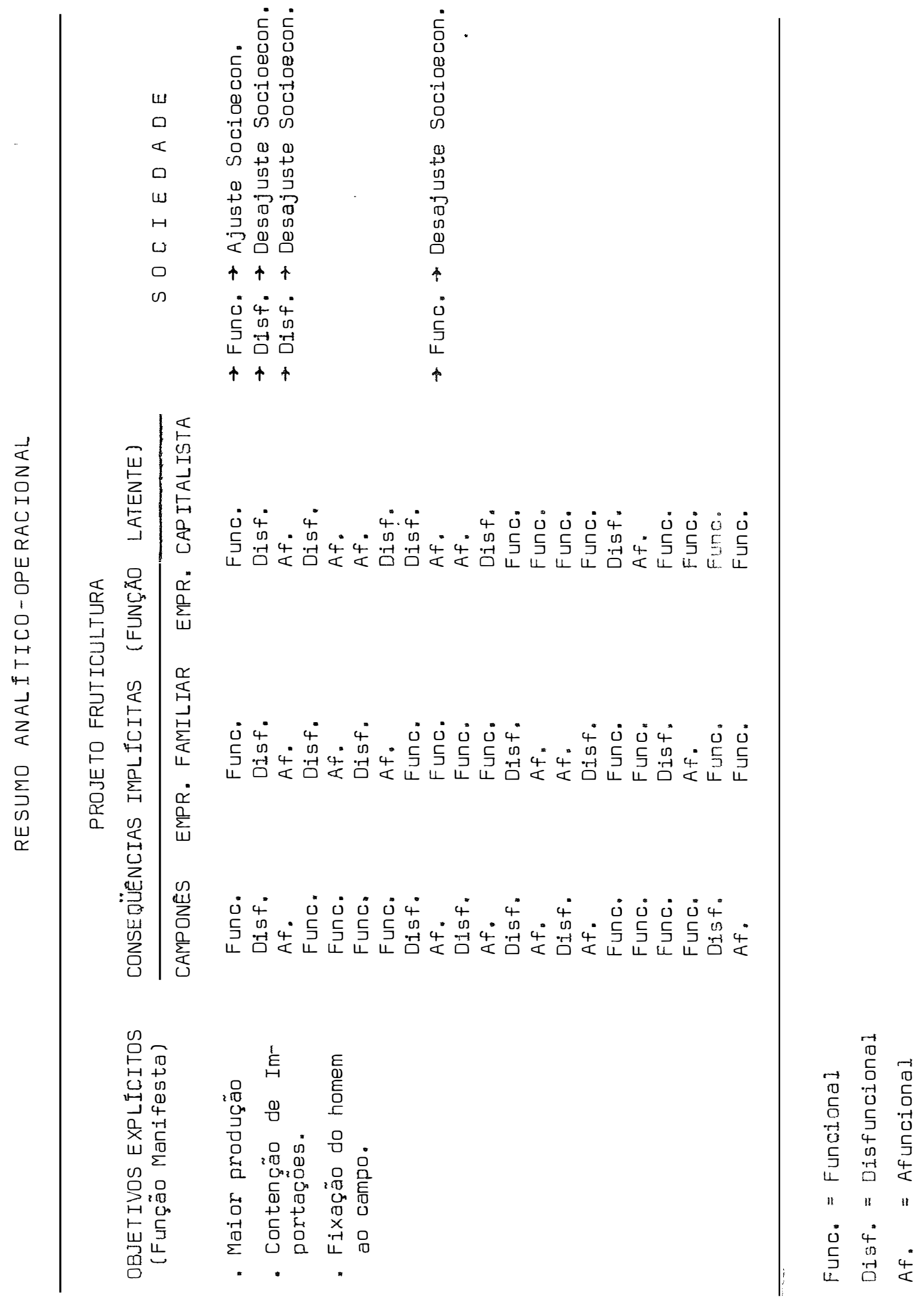




\subsection{Hipötese bäsica}

A Fruticultura (como projeto), em sua função manifesta, demonstra-se funcional para a sociedade e, (como ati vidadel em sua dimensão latente, produz diferentes resultados funcionais para as categorias de produtores rurais, gerando por consequência, um desajuste sócioeconómico do sistema social rural. 
.46.

\section{CONTEXTO E PROCEDIMENTO DO ESTUDO}

\subsection{Area de estudo}

O presente estudo é desenvolvido no Município de Iratí, situado no sul do Paraná, a $150 \mathrm{~km}$ de Curitiba, capital do Estado, e tem como coordenadas geográficas $25^{\circ} 27^{\prime} 56^{\prime \prime}$ de latitude sul e $50^{\circ} 37^{\prime}$ '51" de longitude W. Gr. Limita-se ao norte com Imbituva e Prudentópolis; ao oeste, com Guarapuava; ao sul, com Rio do Sul e Rebouças; e, ao leste,com Te xeira Soares.

É componente de microrregião homogênea, que le va o nome de Iratí, constituída pelos municípios de: Imbituva, Mallet, Rebouças, Teixeira Soares, Iratí, Prudentópolis e Rio Azul.

$$
\text { Iratí ocupa } 976 \mathrm{~km}^{2} \text {, com } 39.203 \text { habitantes as- }
$$


.47.

sim distribuídos: 16.209 na zona urbana e 23.094 na zona rural.

A sede municipal está a 812 metros de altitude, caracterizando-se por um clima frio e úmido, registrando-se fre qüentes geadas. A temperatura atinge anualmente uma média de $24^{\circ} \mathrm{C}$, média das mínimas de $11^{\circ} \mathrm{C}$ e média compensada de $17^{\circ} \mathrm{C}$.

$$
\text { A topografia é bastante acidentada, sendo que }
$$

dois terços da área pode ser considerada montanhosa. Com fertilidade do solo bastante baixa e acidez pronunciada, a região apresenta, de maneira geral, baixo indice de produtivida de agrícola. Destacam-se, em termos de principais culturas, o milho, a batata, o arroz e a cebola.

Observações realizadas revelam a concentração das culturas mencionadas em pequenas e médias propriedades agrícolas. Conforme mostra a Tabela 7,71,4\% das propriedades agrícolas situam-se em estratos com área inferior a 20 ha, ocu pando 32,8\% da área total. Entre os estratos de 20 a 100 ha, tem-se $27,6 \%$ das propriedades ocupando $52,9 \%$ da área total das propriedades agrícolas. 
.48.

Tabela 7 - Estrutura Fundiária de Iratí - 1972.

\begin{tabular}{|c|c|c|c|c|}
\hline \multirow{2}{*}{ ESTRATOS } & \multicolumn{2}{|c|}{ PROPRIEDADES } & \multicolumn{2}{|c|}{ AREA TOTAL } \\
\hline & $N^{8}$ & $\%$ & $\mathrm{Ha}$ & $\%$ \\
\hline - & 1.087 & 25,8 & $2.866,4$ & 3,8 \\
\hline$-\quad 10$ & 821 & 19,4 & $6.149,4$ & 8,0 \\
\hline $10-15$ & 646 & 15,3 & $8.026,3$ & 10,5 \\
\hline-20 & 461 & 10,9 & $8.894,7$ & 10,6 \\
\hline $20-50$ & 1.002 & 23,7 & $29.404,5$ & 38,5 \\
\hline $50-100$ & 163 & 3,9 & $10.968,9$ & 14,4 \\
\hline + de 100 & 42 & 1,0 & $10.959,8$ & 14,3 \\
\hline $\begin{array}{lllll}T & 0 & T & A & L\end{array}$ & 4.222 & 100,0 & $76.470,0$ & 100,0 \\
\hline
\end{tabular}

FONTE: INCRA $(1972)$.

0 municipio de Iratí, assim como toda a microrregião, é marcada por uma população de etnia astante di versificada. Assim, os agricultores são, em sua maioria,descendentes de imigrantes europeus (Poloneses, Holandeses, Alemães, Italianos e Ucraínos). Instalaram-se em núcleos, em di ferentes pontos do município. A maior concentração em deter minados locais, dadas as condições de solo ou de estrutura viária do município, fez surgir importantes núcleos, hoje elevados a distritos: Gonçalves Júnior, Guamirim e Itapará.

A ocupação de lotes no local, num primeiro momento, deu-se espontaneamente, sendo mais tarde dirigida pelo governo federal. Em 1908 instalou-se, através de órgãos fede rais, os núcleos de Gonçalves Júnior e Itapará, sendo Holande 
ses os primeiros imigrantes a chegarem à colōnia Gonçalves Jú nior.

A localização de Iratí é estratégica,pois, situa-se próximo aos polos dinámicos de Curitiba e de Ponta Grossa. O acesso a esses centros serve de entroncamento a ou tros, tais como são Paulo e Rio de Janeiro, facilitado por es tradas de rodagem asfaltadas. Iratí dista apenas $80 \mathrm{~km}$ de Pon ta Grossa, $150 \mathrm{~km}$ de Curitiba e $108 \mathrm{~km}$ de Guarapuava. É servido, ainda, por estradas com boas condições de tráfego, tais como: Irati-Imbituva, Irati-Guarapuava, Via Inácio Martins, Iratí-União da Vitória, Iratí-Ponta Grossa e Via Teixeira Soa res. Além de estradas de rodagem. Iratí é servida pela Rede Ferroviária Federal. As estradas que ligam o interior do município à cidade oferecem boas condições de tráfego o ano todo.

Circulam no local quatro jornais diários da ca pital do Estado, um de Sãc Paulo, e um semanário local. A Rádio Difusora de Iratí, única no local, possue grande penetração, não somente no interior do município, mas tambēm em locali dades vizinhas. Quatro canais de televisão podem ser captados na zona urbana, sendo esta aindabeneficiada pelo sistema telefónico de discagem direta (DDD).

Três agências bancárias (Banco do Brasil, Banco do Estado e Bamerindus), mais a Caixa Económica Federal, centralizam o movimento financeiro. A cidade possui indústria de beneficiamento de trigo, milho e arroz e de transfor 
mação de madeira, totalizando 91 estabelecimentos industriais. Segundo informação obtida no IBGE local, $90 \%$ da produção agrícola é comercializada por intermediários. Existem duas organizações cooperativas constituídas por produtores rurais: a Cooperativa Agrícola de Iratí Ltda e a Coopera tiva de Produtores de Leite. A segunda centraliza toda a comercialização de leite, enquanto que a primeira concentra-se mais na comercialização da soja, do trigo e do feijão.

Uma estação experimental, vinculada ao Institü to Agronómico do Paraná, testa tecnologias, que são preconiza das pelo sistema de pesquisa à microrregião.

\subsection{Descrição geral da ärea}

\subsubsection{Aspectos socioculturais}

Os agricultores agrupan-se em núcleos, sendo que a ärea residencial nem sempre se situa próxima a área de cultivo da lavoura, que dista às vezes de 5 a $6 \mathrm{~km}$, não permitindo que os produtores regressem nas horas das refeições. Nessa situação, a alimentação básica diária é levada até o local de trabalho por um dos filhos ou pela própria esposa do produtor. Quando a mulher compõe a força de trabalho e exis tem filhos pequenos, estes acompanham os pais permanecendo o dia todo nos arredores da lavoura. Quando há poucos componen tes na família, isto é, 2 a 3 filhos, a mulher participa dos trabalhos da lavoura. A medida que a família conta com maior 
nümero de braços $\{3$ e mais\}, a mulher limita-se a trabalhos domésticos. Quando nos referimos à mulher, queremos dizer a esposa do chefe da família, pois, quanto às filhas após 7 a 8 anos de idade integram ativamente o contingente de mão-de-obra, embora, muitas vezes, limitando-se a trabalhos que exigem me nor dispêndio de energia física.

Como instrumentos de trabalho, geralmente, é utilizado o arado de aiveca e a grade, movidos à tração animal, enxada e, em alguns casos, carpideiras e plantadeiras. Normalmente, a carroça movida a cavalo constitui o veículo de locomoção para a família e pare o transporte de instrumentos e de produtos agrícolas, do local de residência á propriedade agrícola, e desta ao comércio local. Com relação à utilizaçäo de maquinaria moderna, ainda são poucos que dela se utili zam. Segundo dados da EMATER-PR., no ano agrícola 75/76 haviam no município 252 mäquinas modernas para um total de 4.222 propriedades agrícolas. A Tabela g nos fornece dados sobre os equipamentos pesados, utilizados pelos agricultores de Ira ti, no ano agrícola $1375 / 76$.

Tabela 8 - Máquinas agrícolas existentes no município de Irati. 1975/1976.

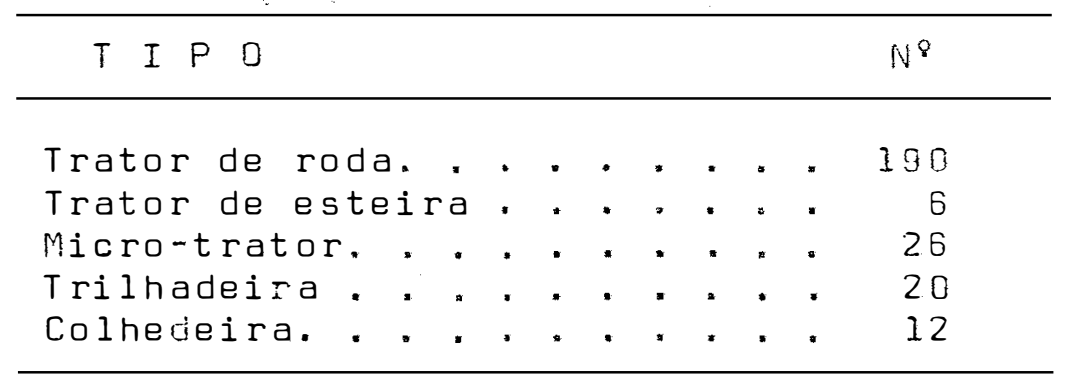

FONTE: EMATER-PR \{1976\}. 
A organização do trabalho se restringe ao àmbito familiar, raramente se encontrando formas de trabalho em bases coletivas, tais como os chamados mutirões, ou quaisquer outras baseadas na permuta de trabalho.

Aos domingos e dias santos, a família não se desloca para o trabalho, indo à igreja pela manhã. Após o cul to, os grupos se reunem nos botequins, nos lares ou num campo de esportes, seja para trocar idéias sobre a atividade agríco la em geral, para se atualizar sobre os assuntos gerais do po voado, ou para lazer. Periodicamente, são realizados jogos e encontros entre clubes de outros núcleos municipais ou intermunicipais. A religião católica ou protestante, principalmente, determina os dias feriados no campo, bem como as festas em suas respectivas Igrejas. Embora grupos de descendência diversa possam pertencer à mesma religião, é interessante observar que alguns grupos conservam os rituais de origem e constituem um grupo à parte. Os Ucranianos erigiram sua própria igreja, mesmo havendo uma igreja da mesma religião, frequentada por grupos de pessoas de outra origem como a polonesa ou italiana. A população rural, em sua maioria, pertence a uma ou outra religião, mantendo-se fiel às suas crenças e princípios religiosos.

A presença do curandeiro é encontrada em vários núcleos, e persistem crenças que são observadas no plantio ou na condução de lavouras. Assim, "batata deve sex plan tada na lua cheia para dar graüda", "muzher grävida não pode 
entrar em horta que o piolho ataca as hortaligas".

No àmbito da economia, na atividade ocupacional, é que os atores são mais intensamente persuadidos a adotar novos meios relacionados à produção, tanto no que se refe re aos aspectos conceituais, quanto instrumentais. Assim, há de se considerar a ação dos agentes de Assistência Técnica e Extensão Rural que atuam no processo de mudança. 0 Serviço de Extensão Rural já vem atuando, através de seus projetos,por um perfodo de 22 anos, mediante técnicos que assistem técnica e organizacionalmente os produtores.

Novas técnicas de produção fazem parte de alternativas que configuram novos meios que visam assegurar a consecução de metas do produtor. Atualmente, uma equipe de cinco técnicos atua no local. Um agrónomo presta serviços de assistência técnica no setor de fruticultura; um zootecnista assiste o setor de pecuária leiteira; um agrônomo desenvolve atividade junto à Cooperativa Agrícola Irati Ltda; e um técnico agrícola com uma técnica em Bem-Estar Social integram a equipe que executa o projeto ligado à agricultura de "Bai$x a-\operatorname{Ren} d a^{\prime \prime}$

o trabalho com Juventude Rural é executado no local desde 1968, por uma equipe constituída por um técnico em Juventude Rural e por uma técnica em Bem-Estar Social.

O serviço de Extensão Rural atinge a população rural através de meios grupais, individuais e massais,assim como através de elementos do povoado que dosfrutam de 
prestígio e de poder influenciador, servindo como instrumento irradiador das inovações a disseminar. o rādio é uma das grandes forças comunicadoras no local, atingindo a maioria da população, que possui receptor e ouve os programas de orien tação agrícola.

Em perído anterior ao trabalho da EMATER-PR,

a Secretaria da Agricultura também prostava serviços assisten ciais. Atualmente, a assistência técnica é apenas prestada peio Serviço de Extensão Rural, vinculado à Secretaria da Agricultura. Evidentemente, os atores rurais não estão suje tos apenas à ação dos agentes oficiais de mudança no meio rural mas, também, de elementos diversos que passam a constituir novos componentes de orientação. Entre eles, situam-se os agentes vendedores de produtos agrícolas, os técnicos da cooperativa de leite, os agentes de comércio em geral, elemen tos ligados às atividades urbanas e, ainda, os recursos de co municação, que, em conjunto, compõem um universo de novos pa dröes, que penetram o setor rural, seja através de produtos de origem externa ao subsistema, seja através de idéias e estilos vivenciais.

De maneira geral, novos meios de produção já vem sendo adquiridos pelos produtores. Assim, dificilmente se encontra um produtor rural que não utilize pelo menos uma ino vação tecnológica qualquer. Contudo, percebe-se que algumas dessas inovações são usadas incorretamente evidenciando desco nhecimento sobre alguns dos seus atributos. Deparou-se com si 
tuações, em que o produtor rural não tinha o mínimo de informação necessária para o manejo adequado de modernos instrumen tos de produção. Pode-se citar como referēncia o entrevistado $n^{8} 33$ que, desinformado sobre a natureza da tecnologia (no caso adubo nitrogenadol, ap licou em sua lavoura quantidades excessivas do produto, com localização incorreta,o que o levou a perder $80 \%$ de sua cultura. Essa situação, evidentemente, deixa o ator prevenido contra a tecnologia da adubação e outras inovações.

Ainda no que se refere ans órgãos de atuação no meio rural, destace-se a Cooperativa Agrícola de Iratílta, organização estabelecida em bases cooperativistas, que visa a organização da produção do produtor rural. A cooperativa,atual mente, desenvolve junto à população, através de técnicos trei nados, um trabalho de doutrinação cooperativista, visando uma participação mais efetiva e eficiente dos cooperados e uma ex pansão do seu quadro. Contudo, problemas de ordem administra tiva, técnica e gerencial, vêm influindo negativamente no tra balno, levando o agricultor a desacreditar na organização que, teoricamente, seria o instrumento adequado para resolver um dos seus principais problemas, a comercialização da produção.

A Cooperativa de Produtores de Leite centraliza toda a produção da pecuária leiteira, cuja expansão se deu através dos planos de Desenvolvimento da Pecuária Leiteira (PDPL), executado pela Cooperativa em convēnio com a EMATER-PR. 


\subsubsection{Meios e condicionantes básicos da situação}

Como alternativas principais, que se oferecem como meio para a realização de metas, têm-se na situação as culturas de milho, feijão, batata, cebola, arroz, soja e trigo. Batata, feijão, milho e cebola constituem espécies tradicionalmente cultivadas. Deve-se ressaltar que a batata tem projetado o local no cenário económico, como importante forne cedor desse produto, abastecendo cidades tais como: Curitiba, São Paulo e Rio de Janeiro.

Nos últimos anos novas alternativas tem surgi do no local, entre as quais a cultura da soja e de trigo, cul tivadas por proprietários de grandes extensões de terra adequa das a tais produtos. Contudo, elas não se expandiram a ponto de prejudicar a produção de culturas de subsisténcia. Os produtores, que se lançaram na nova alternativa, são proprietários de grandes áreas e apenas as exploram mais intensivamente. Houve expansão de área plantada mas não substituição de cultura.

Predominando no local pequenos e médios proprietários de terra, e dada a carência de área e de recursos para investir, eles se vēem impossibilitados de desenvolver este tipo de empreendimento agrícola. Assim, o cultivo rotativo de soja e de trigo encontra-se, na atualidade, estabelizado, não sofrendo expansão, seja pelas próprias limitações estruturais da região, seja por aspectos relacionados ao pre- 
ço e à demanda do produto. No que se refere à cultura do tri go, houve uma redução da área do cultivo, dada a carência de sementes adequadas à região, levando os atores a substituir a cultura de trigo pela cultura de cevada.

Como componentes de novas alternativas, a pe cuária de leite constitui uma atividade que já teve seu momen to dinámico de expansão. É um programa que vem sendo executa do desde 1974, em convênio com o Serviço de Extensão Rural e faz parte do Plano Nacional de Desenvolvimento da Pecuária Leiteira. Na atualidade, o plano encontra-se parcialmente es tagnado por falta de recursos, destinados ao financiamento dos projetos de instalação e manutenção de empreendimento leite ro.

Ainda no plano das novas alternativas, a fruticultura - atividade em anälise no presente estudo - vem sen do executada como projeto por um período de cinco anos.

As diversas alternativas, principalmente as que são incluídas em programas de fomento à produção, vêem-se contempladas, além da assistência técnica, com fatores de estímulo com o financiamento de custeio da produção. Assim, os programas de crédito rural, abrangendo, principalmente, as cul turas de soja, trigo, batata, milho e feijão, tem por objetivo dotar os atores de recursos para a execução de seus planos, através de diversas modalidades: Crédito corrente, supervisio nado, educativo e de repasse via cooperativa. Ainda mais, vá rios programas especiais refletiram e refletem a politica de 
crédito rural, tais como: o Plano de Desenvolvimento da Pecuária Leiteira (PDPL); o crédito para a Fruticultura; o Programa de Silos e Armazéns (PRONAZEM); e o Programa de Calcário (PROCAL).

A comercialização dos produtos agrícolas é rea lizada em grande parte por intermediários da região, de quem a maioria dos agricultores são dependentes. Apenas a Coopera tiva Agrícola de Irati tem armazéns sob controle de produtores rurais. Contudo, tem uma capacidade de armazenamento de produtos menor que os dos intermediários. Conforme dados do IBGE, existem no local 28 intermediários com capacidade total de armazenamento de $62.526 \mathrm{~m}^{3}$, para uma estimativa de 50.020,8 toneladas, aproximadamente. Os quatro silos existentes no lo cal possuem 7.010 t. de capacidade, dos quais um deles perten ce a CIBRAZEM com capacidade de 2.400 toneladas. Comparativamente, temos uma capacidade armazenadora de 54.610 toneladas nas mãos de intermediários, enquanto que apenas $8.400 \mathrm{t}$. de produtos agrícolas podem ser armazenados sob controle estatal. Nas mãos de intermediários encontram-se, pois, os prodü tos de maior importáncia económica da região, quais sejam, fei jão, milho, batata e cebola.

O leite constitui o único produto comercializa do totalmente por organização cooperativista. Embora a fruti cultura constitua uma atividade ainda não muito expressiva economicamente, já surgem os interessados na sua comercialização, à medida que a produção se avoluma. Na última safra, se- 
gundo depoimento dos fruticultores, enquanto alguns entregavam o produto direto aos consumidores locais a um preço de $\operatorname{Cr} \$ 8,00$ a $\operatorname{Cr} \$ 10,00$ o kg da fruta selecionada, outros entregavam-na a intermediários a Cr\$20,00 a caixa de $20 \mathrm{~kg}$. Bons negócios foram realizados por aqueles que dispunham de meios de transporte, tendo condições de colocar os produtos em mercados vizinhos. A fruticultura carece de uma estrutura de co mercialização orientada aos interesses do fruticultor e que abranja desde a classificação e acondicionamento de frutos até a venda do produto.

Os fatores relacionados à comercialização dos produtos agrícolas demonstram, pois, estar fora do controle do produtor, que tampouco se acha organizado para interferir ou reivindicar medidas, que possam beneficiá-lo diretamente na obtenção de melhores preços. Estes, oscilando constante mente, condicionam todo o rendimento económico da produção agrícola e influem diretamente no comportamento do agricultor com relação à orientação da unidade de produção para a subsis tência ou mercado. Embora os preços mínimos sejam fixados anualmente por órgãos do governo, não correspondem, muitas vezes, aos custos reais, sob a ótica do produtor. Esta situação gera comportamentos que serão analisados no quinto segmento deste trabalho.

As alternativas agrícolas, cujos resultados económicos, além de se verem condicionados por fatores relacionados à comercialização, devem ajustar-se às caracterís- 
.60 .

ticas de cada propriedade, em grande parte bastante limitantes no que se refere à fertilidade, topografia, tamanho e distância da sede do município.

\subsection{A Pesquisa}

\subsubsection{Material de Pesquisa}

Foram utilizadas as técnicas de observação e Entrevista não diretiva. A pesquisa foi orientada por um roteiro, elaborado com elementos do sistema de conceitos do qua dro analitico. O roteiro de pesquisa, embora estruturado em suas partes, nāo visava transformar a pesquisa em um esquema rígido, quanto a sequência e os vérios aspectos a serem abordados. Isto quer dizer, que o desenrolar do processo de inte raçāo entre entrevistador e entrevistado é que indicava as questões a serem abordadas.

Além do roteiro de pesquisa foi aplicado um questionário visando o registro de dados quantitativos diretamente relacionado com o processo de produçāo agrícola.

\subsubsection{Entrevistas}

Na maioria das vezes, a entrevista foi realiza da no local onde o agricultor se encontrava lavrando a terra. Isso contribuiu para aumentar a confiabilidade nos dados, ten do em vista o clima de informalidade, que se procurava culti- 
.61.

var durante o processo de obtenção dos mesmos. Na medida que se obtinha essa informalidade na entrevista mais facilmente fluíam os elementos de interesse. Bastava conduzir o diálogo para as questões constantes do roteiro e os elementos pretendidos emergiam espontaneamente, sem que houvesse necessidade de formular perguntas diretas, através das quais se enfrenta ria o risco de se obter respostas induzidas.

A informalidade no relacionamento näo foi difí cil de ser obtido em razäo do entrevistador já conhecer vários aspectos da área de estudo, e de sua ação no local como profissional. Conhecendo de certa forma alguns problemas relacionados à tecnologia agrícola e outros de ordem infraestrut $\underline{u}$ ral, neles se apoiava para orientar a primeira parte do diálo go.

Procurou-se apreender aquelas orientações rela cionadas com a atividade produtiva, mais especificamente aque las que tinham relações com alternativas novas, entre elas a fruticultura.

As entrevistas foram realizadas com auxílio de um gravador. Nas primeiras, cientificava-se o entrevista do da sua utilização para o registro do diálogo. Constatou-se, porēm, que a presença do aparelho gerava uma situação incômoda e, assim, nas entrevistas subseqüentes, näo se informou de sua utilização, sendo o mesmo mantido afastado da vista do en trevistado.

Não houve nenhum caso de rejeição à entrevista. 


\subsubsection{Critērio para estratificação dos produtores en trevistados}

Inicialmente, foram identificadas duas grandes categorias de produtores: 1) Os produtores de origem agrícola, que praticam a agricultura como única e principal função: "Pro dutores Genuinamente Agricolas". 2) Os produtores que prati cam a agricultura em caráter temporário ou complementar à outra atividade não agrícola: "Produtores Parciais". No caso es pecifico dos fruticultores serão denominados: Fruticultores Genuinos e Fruticultores Parciais, respectivamente.

Os Produtores Genuínos, por sua vez, foram categorizados em conformidade com o critério de classificação de unidades produtivas desenvolvido por MOLINA FILHO (1976). Este autor classifica em quatro tipos básicos, as unidades de produção agrícola no Brasil CUnidade Camponesa, Empresário Fa miliar, Empresário Capitalista e Latifúndiol, e considera como fundamentais três variáveis para discriminar as categorias de produtores: a) a participação no mercado; b) relações de produçào: cl diversificaçào agrícola.

- Participasão no mercado: refere-se à relação entre o valor total da produção obtida e o valor total da pro dução comercializada. D indice menor ou maior de 50\% discrimina a categoria camponês e empresa familiar, respectivamente.

- Relações de producão: relaciona-se com o tipo de mão-de-obra utilizada pela unidade produtiva, que pode ser: 
familiar, assalariada ou, eventualmente, parceira. A mão-de-obra assalariada relaciona-se com a empresa capitalista.

- Diversificasão agricoza: relaciona-se com o grau de especialização de empreendimento agrícola. 0 índice é fornecido pela fórmula:

$$
0=\frac{1}{\sum f_{i}^{2}}
$$

onde:

$$
\begin{aligned}
& D \text { = grau de diversificação. }
\end{aligned}
$$

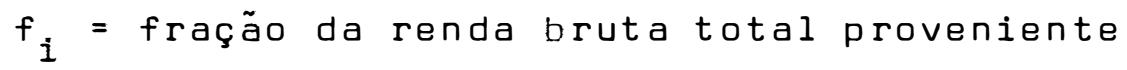

A participação da mão-de-obra foi calculada à luz da tabela abaixo, conforme ERVEN (1969:137) citado por MOLINA FILHO (1976).

$I D A D E$

$$
\begin{aligned}
& 10-14 \\
& 15-17 \\
& 18-53 \\
& 60 \text { e mais }
\end{aligned}
$$

\section{EQUIVALENTE-HOMEM}

\begin{tabular}{cc}
\hline Homem & Mulher \\
0.5 & 0.5 \\
0.8 & 0.8 \\
1.0 & 0.8 \\
0.8 & 0.5
\end{tabular}




\subsubsection{Estratificação dos entrevistados}

Todos os 49 produtores envolvidos no projeto fruticultura foram considerados no estudo. Neste total incluem-se produtores que já cultivavam frutas, outros que ainda não praticavam fruticultura orientada para o mercado, mas que já experimentavam a atividade com reduzido número de pés, e, ainda, outros que apenas mantiveram contatos com os agentes de extensão.

Foram entrevistados 14 agricultores, genuinos e parciais não fruticultores, tomados ao acaso, visando obter maior segurança para explicar os aspectos relacionados à re jeiçäo da fruticultura. No total foram entrevistados 63 produtores, entre fruticultores e não fruticultores.

Dos 63 produtores entrevistados, 40 são produtores genuinos e 23 produtores parciais. Posteriormente, os da dos de dois produtores genuinos (um parceiro e um arrendatáriol foram rejeitados por não se enquadrarem nos requisitos exigidos para o presente estudo.

Os dados referentes à categorização dos produtores genuinos, segundo os critérios estabelecidos, são apre sentados na Tabela 9 . 
.65.

Tabela 9 - Situação dos Produtores Genuínos entrevistados, em relação a mão-de-obra, grau de participação no me $\underline{-}$ cado e grau de especialização.

\begin{tabular}{|c|c|c|c|c|c|}
\hline \multirow{2}{*}{ ENTR. } & \multicolumn{3}{|c|}{$M \bar{A} O-D E-O B R A$} & \multirow{2}{*}{$\begin{array}{l}\text { GRAU DE PAR } \\
\text { TICIPAÇÃO } \\
\text { NO MERCADO }\end{array}$} & \multirow{2}{*}{$\begin{array}{l}\text { GRAU DE } \\
\text { ESPECIA } \\
\text { LIZAÇÄO }\end{array}$} \\
\hline & Familiar & Assal. & Outros & & \\
\hline 1 & 4,4 & - & - & 0,80 & 0,32 \\
\hline 2 & 6,1 & - & - & 0,74 & 0,350 \\
\hline 3 & 4,0 & - & - & 0,60 & 0,244 \\
\hline 4 & 6,4 & - & - & 0,60 & 0,234 \\
\hline 5 & 1,0 & 2.0 & - & 0,98 & 0.585 \\
\hline 6 & 1,8 & - & - & 0,51 & 0,516 \\
\hline 7 & 3,0 & - & - & 0,71 & 0,315 \\
\hline 9 & 5,0 & - & - & 0,62 & 0,270 \\
\hline 10 & 3,0 & - & - & 0,94 & 0,438 \\
\hline 11 & 2,6 & - & - & 0,23 & 0.261 \\
\hline 12 & 2,0 & - & - & 0,66 & 0,382 \\
\hline 13 & 3,4 & 1,0 & - & 0,86 & 0,530 \\
\hline 14 & 2.0 & 2,0 & - & 0,97 & 0,317 \\
\hline 15 & 1,8 & - & - & 0,55 & 0,327 \\
\hline 16 & 1,8 & - & - & 0,89 & 0,263 \\
\hline 17 & 1,8 & - & - & 0,57 & 0,263 \\
\hline 18 & 2,6 & - & - & 0,68 & 0,289 \\
\hline 19 & 1,8 & - & - & 0.59 & 0,497 \\
\hline 20 & 1,8 & - & - & 0,66 & 0,250 \\
\hline 21 & 1,0 & 2,0 & - & 0,62 & 0,289 \\
\hline 22 & 3,4 & - & - & 0,62 & 0,403 \\
\hline 23 & 1,8 & - & - & 0,47 & 0,220 \\
\hline 24 & 1,0 & 2,0 & - & 0,84 & 0,406 \\
\hline 26 & 3.4 & - & - & 0,59 & 0,202 \\
\hline 27 & 1,8 & - & - & 0,69 & 0.347 \\
\hline 28 & 1,8 & - & - & 0,57 & 0.248 \\
\hline 31 & 1,8 & - & - & 0,48 & 0,281 \\
\hline 32 & 5,4 & - & - & 0,70 & 0,196 \\
\hline 33 & 2,6 & - & - & 0,52 & 0,222 \\
\hline 34 & 3,0 & - & - & 0,85 & 0,344 \\
\hline 35 & 2,6 & - & - & 0,54 & 0,245 \\
\hline 36 & 1,8 & - & - & 0,76 & 0.197 \\
\hline 37 & 1,8 & - & - & 0,57 & 0,196 \\
\hline 41 & 3,4 & - & - & 0,82 & 0,581 \\
\hline 42 & 1,0 & 2,8 & $4: 0$ & 0,47 & 0,290 \\
\hline 44 & 3,0 & 1.0 & - & 0,96 & 0,418 \\
\hline 57 & 1,8 & 1,0 & - & 0,98 & 0,382 \\
\hline 59 & 4,4 & - & - & 0,62 & 0,396 \\
\hline
\end{tabular}


.66.

Se verificarmos cada variável separadamente, constata-se que, com relação à mão-de-obra, predomina entre os produtores genuínos estudados a força de trabalho familiar. Somente as unidades $5,21,24$ e 42 tem um equivalente em mão-de-obra familiar inferior á mão-de-obra assalariada.

Quanto à variável Grau de Participação no Mercado, os dados revelam que os produtores, de modo geral,orien tam sua unidade de produção agrícola para o mercado, pois prä ticamente todos eles vendem mais de $50 \%$ de sua produção. Apenas um produtor, o $n^{8} 11$, participa do mercado com $23 \%$ do valor total de sua produção.

Poucas unidades de produção revelam alto grau de especialização de culturas agrícolas. Somente as unidades 5, 6, 13,19 e 41 estão especializados em grau equivalente ou superior a 0.5 .

A Tabela 9 revela, pois, que a quase totalida de de produtores genuínos orientam sua produção predominantemente para o mercado, mesmo praticando a policultura.

Segundo critérios já definidos, a classificação das diversas unidades é baseada na combinação entre as très variáveis discriminantes principais. Nesta perspectiva, em termos absolutos, temos uma grande homogeneidade de produ tores na amostra. Observa-se que, a rigor, apenas duas unidades se distanciam das demais. São as unidades 5 e ll. A uni dade 5 apresenta uma predominância de mão-de-obra assalariada, um grau de participação no mercado correspondente a 0,98 e um 
grau de especialização superior a 0,5 , constituindo-se numa empresa capitalista. A unidade 11 revela utilização de mão- de-obra familiar, participação no mercado $(0,23)$ inferior a 0,5 e grau de especializaçäo também inferior a 0,5, classificando-se como camponesa.

As demais 36 unidades, considerando os dados apontados pelas variáveis, são categorizadas como Empresas Fä miliares. Destas, 19 já se dedicam à exploração de frutífe ras.

Apenas a categoria dos Empresários Familiares permite a reconstrução do sistema de ação, uma vez que não se poderia com apenas uma unidade de cada categoria (Campones e Empresārio Capitalista), representar a orientação normativa de uma categoria de atores. O grupo de produtores genuinos é representado pela categoria Empresário Familiar.

Serão excluídos da análise relacional ator-sí tuação aqueles produtores que tradicionalmente não exercem a atividade agrícola, isto é, os produtores parciais. Essa orien tação tem por base a pretensão de se detectar a estrutura organizacional da ação de um sistema constituído por atores que desempenham atividades tradicionais em um sistema social em mudança.

Por outro lado, quando da realização da análise dos resultados ou consequências da atividade fruticultura, serão consideradas as duas categorias envolvidas no projeto, istoé, o Empresário Familiar e os Fruticultores Parciais. 
.68.

\section{ANALISE E INTERPRETAÇĀO}

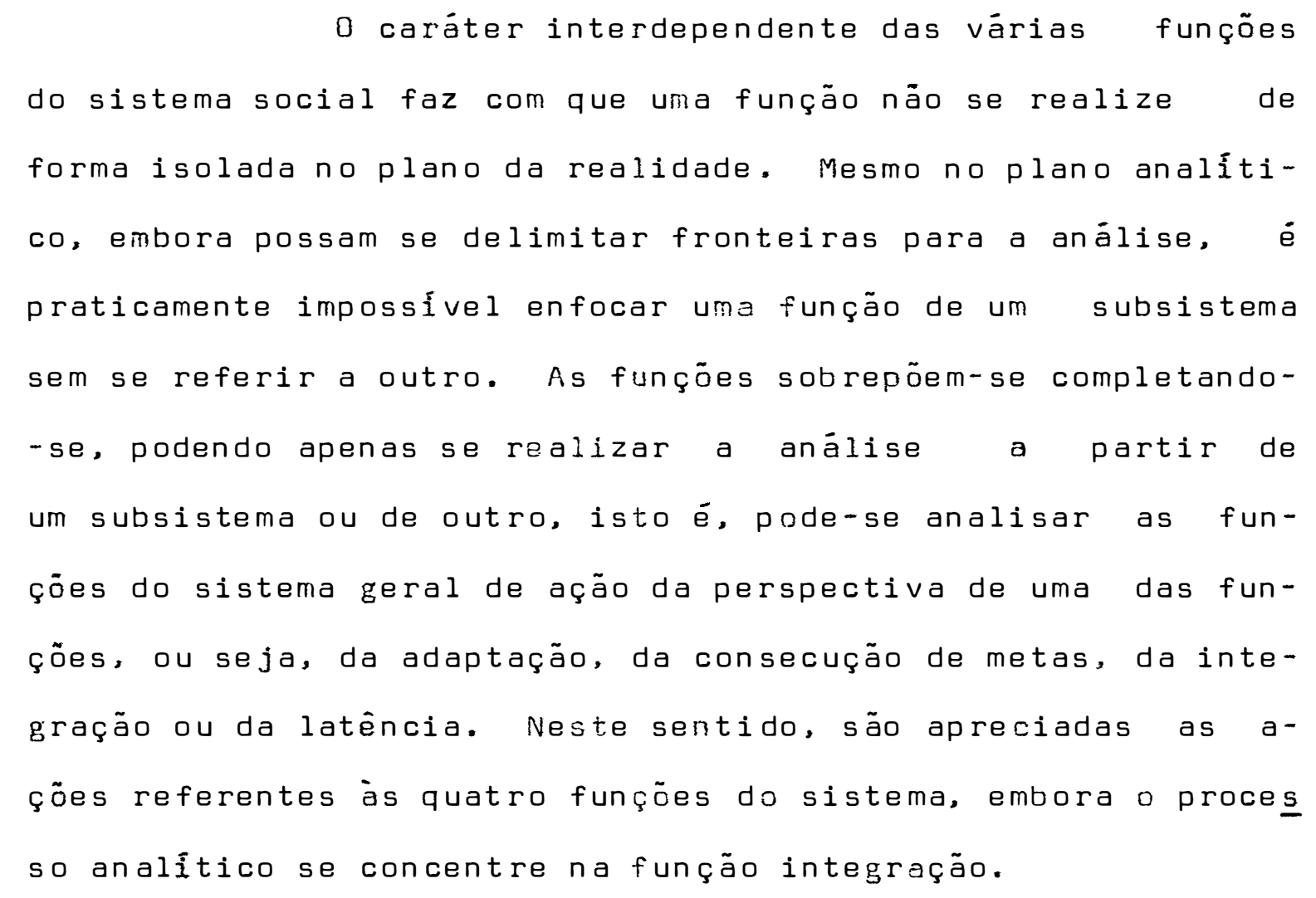


.69.

A exposição que segue consiste de uma articulä çäo básica entre os vários aspectos dos subsistemas cultural, personalidade e social. Trata-se da orientação dos atores em busca de sua realização num processo de adaptação às condições gerais da situação.

Procura-se projetar os elementos que são contemplados objetivamente na eleição de uma ou de outra alternativa, definida como objeto-meio, constituinte da situação. A pluralidade de elementos orientadores da ação, inerente aos diversos objetos situacionais, adquirem unidade, compondo o uni verso de ação, ou o sistema de orientação e referência dos produtores rurais.

\subsection{Função adaptação}

A adaptação do sistema de ação da categoria Empresário Familiar, evidentemente, está relacionada à sua in serção no quadro da sociedade. Adaptando-se às várias situa ções impostas pelo sistema inclusivo, o setor rural sofre rea justes, transforma-se e molda seu caráter de persistência. As ações oriundas do meio externo desencadeiam o processo de transformação.

Dois aspectos são ressaltados ra anälise da função adaptação: a adaptação ao meio natural e a adaptação às atividades propostas pelo sistema inclusivo. 


\subsubsection{A adaptação ao meio natural}

D processo produtivo agrícola local realiza-se sobre uma topografia ondulada a semi-ondulada,que dificulta a mecanizaçẽo agrỉcola. Esta característica da topografia na região faz com que sejam exploradas culturas (como milho, fei jão, cebola, batatal que podem dispensar o uso de máquinas agrícolas modernas. Esta condição local permite também persis tir uma agricultura apoiada na força de trabalho familiar. 0 baixo valor da terra, em razão de sua característica topográ fica e de sua baixa fertilidade, permite o acesso de pequenos produtores agrícolas à terra e não atrai grandes empresários interessados em praticar a agricultura em grande escala, atra vés da mecanização, como nas regiões do Oeste e Norte do Para nä.

A agricultura de alimentos constitui,pois, uma atividade que se ajusta às características da situação.

A maior parte das unidades de produção pratica o sistema de pousio*. Este sistema constitui uma solução encontrada pelo produtor que, segundo sua percepção considera inviável a adubação em terras onduladas. Exemplo típico ocorre com o calcário que, ao ser adicionado ao solo, age como des-

\footnotetext{
* Sistema que consiste da prática de recuperação da fertilidade do solo de forma natural. Após um período de exploração, o solo é deixado em repouso, por um período de 3 anos a mais para que a natureza lhe devolva os nutrientes exauridos pelas plantas cultivadas.
} 
compactador, tornando a camada arável mais friável e, assim, mais sucetível à lixiviação e à erosão.

....."o pessoar planta um pouco com adubo. um pouco assim... pra calcareá ninguém põe calcário... aqui caindo uma chuva forte leva tudo embora... a terra fica muito mole enquanto com o adubo não... o calcário é bom, mas tem que por mais no plano" (entr. n' 11 ).

....."aqui nãa dá pra plantä na técnica, o se nhor veja, colocandio adubo ou calcário aqui,es corre tudo" (entr. $n^{8} 9$ ).

o ambiente físico em que se desenvolve o processo produtivo restringe, assim, o uso de insumos modernos nas culturas anuais. Esta característica local limita o uso de meios modernos de produção, como insumos e máquinas modernas, que passam a ser utilizados de forma moderada nessas cul turas.

\subsubsection{Adaptação às atividades propostas}

Visando a obtenção de recursos produzidos na sociedade, o produtor dedica-se às atividades que, na sua pers pectiva, permitem participar com vantagem nas relações de tró ca.

Por outro lado, o maior grau de especialização dos outros setores faz com que o setor rural seja levado a au 
mentar o volume de produção, tanto de alimentos como de matéria-prima para a indústria. Além das atividades tradicionais, como a exploração de milho, feijão, arroz e batata, novas alternativas são propostas ao produtor, como a fumicultura, a fruticultura e a pecuária de leite. Estas novas alternativas passam a ser exploradas para o mercado, paralelamente ás cultural tradicionais que lhes assaguram a subsistência.

..."plantamos de tudo sim, porque se um produto não dá, outro dá. plantamos de tudo, pra vendê e pra comê; se não vendê como comprar o resto?..." (entr. $\left.n^{8} 1\right)$.

..."eu planto para vendê né... sai da boca pra vendê, o que vai se fazê?"... (entr. $n^{8}$ B).

As linhas de exploração voltadas para o mercado são de suma importáncia para o sistema inclusivo, uma vez que cabe ao setor rural a função específica de produzir alimentos. Maior produção para o mercado favorece a sociedade, pois, a especialização do setor rural,consequentemente, leva à busca de produtos de origem não agrícola. Esta especialização do setor agrícola, por outro lado, faz com que diversas linhas de exploração orientadas para o mercado satisfaçam um dos requisitos básicos do sistema, qual seja, o de possibili tar sua participação na troca de seus produtos por outros bens e serviços. 
..." de primeiro, nós plantava mais batata, tri go e milho e feijão, cebola não plantava... não tinha comércio. Batata, por mais barato que fosse, ela eaia, né; podia ter a quantia que quizesse e o trigo tambëm, mas parou de dá.... Ai larguemo a batata... quando ela dáa, ela dá, quando dä bem, no fim, não tem preso; a gente tem que dá de graca e o adubo à muito caro e esse (defensivo) para pulverizar... bem, no fim, a gente perde um dinheiro grande do borso..... no final das contas, dá zero mata zero; o que faz, gasta e não pode ir pra frente... não sobra..." (entr. n $\left.n^{8} 23\right)$.

A articulação do setor rural com o sistema so cial inclusivo se caracteriza pela diversificação das linhas de exploração do sistema produtivo, que reage segundo as oscilações do sistema económico da sociedade. Articulando-se com a sociedade, o ator se depara com novos elementos de orienta ção para sua ação produtiva, os quais são finalmente internalizados no sistema de ação, realizando em última instância um processo de redimensionamento dos padrões de conduta.

A situação é enriquecida pot elementos novos,

- que leva os atores a ajustarem sua habilidade e as suas ati tudes em relação à situação da sociedade.

\subsection{Função consecução de metas}

No desempenho de seu papel, o ator rural, ao de 
finir suas metas, o faz de forma a assegurar a sua subsistên cia, o que é obtido com um sistema tradicional de produção, e busca uma realização econômica através de produtos comerciali záveis. Nesse sentido, duas orientações são dadas concomitan temente à unidade de produção agrícola: a preocupação com linhas de exploração voltadas para o mercado e com culturas para o auto-abastecimento. Culturas de auto-abastecimento ou de subsistência são as necessárias à manutenção da famĩlia (co mo feijão, arroz, leite e seus derivados, frutas, verduras) e as culturas complementares (como o milho) visam a alimentação de animais domésticos e a produção de sementes. A preocupação de manter tais linhas de exploração é tida como racional, pois "já que se está lidando com plantagão, planta-se pro gas to e não precisa comprar". Com exceção de um dos entrevistados, que manifestou propenção em cultivar exclusivamente as linhas voltadas para o mercado, uma vez assegurada retornos positivos, todos os demais sustentaram o interesse de "plantar para o gasto". A preocupação em explorar culturas com boas perspectivas de mercado estão refletidas nos diversos de poimentos deste trabalho e especificamente nas afirmações:

". quando uma cultura dá mais, a gente planta mais daquela; não larga as outras; continua plantando, mas planta menos né... "(entr. $n^{\circ} 28$ ).

"...na lavoura não está dando coisa nenhuma, mas a gente vai plantando o feijão, a cebola 
prä vendë... a gente planta de tudo um pouco, mas aumenta mais esta planta que dá e diminue as outras". (entr. n8 22 ).

"Planto o que mais dá e pega menos chão". lentr. $\left.n^{2} 21\right)$.

A escolna das culturas de mercado constituem pois o resultado de uma reflexão em que são contemplados os vários elementos que permitem alcançar uma maior gratificação económica. Os elementos situacionais percebidos pelo ator rural. relacionados com o papel de produzir produtos agricolas, orientam a racionalização de sua ação.

Infere-se, então, que, com a unidade de produ् ção agrícola, tem-se por meta: (a) a produção de autoabasteci mento visando a alimentação da família e a manutenção da unidade produtiva; e (b) a exploração de culturas de maior perspectiva de mercado, visando a obtenção de um maior rendimento económico. Pode-se constatar ainda dois aspectos básicos e estreitamente relacionados com a obtenção das metas: 1) o bem-estar familiar e 2$\}$ o desejo de ver assegurado o futuro dos filhos.

\subsection{Função integração}

A situação que se projeta analiticamente é cons tituída por diversos objetos orientadores da ação.

Contudo, o uso de tais objetos só se concre 
.76.

tiza quando: (1) o ator visualize a gratificação por ele estruturada; (2) as propriedades gratificantes do objeto mantêm consonáncia com os padrões normativos do ator e (3) os objetos empíricos, condicionantes, que se situam fora de seu controle, viabilizam a obtenção de metas. De acordo com a especificação das metas efetuadas anteriormente, o uso de objeto-meio relacionado com a atividade ocupacional se dá visando atingir aqueles objetivos ou a gratificaçäo definida pelo ator. São definidas como objetos-meios, as diversas linhas de exploração, as práticas e tecnologias agrícolas necessárias para obtenção de maior produção e produtividade.

$$
\text { Referindo-se à utilizaçāo da tecnologia como }
$$
objeto-meio, quatro entrevistados refletiram elementos de orien tação relacionados a objetos não empiricos da situação. Tais elementos situam-se a nível do sistema cultural refletindo padrões costumeiros de orientação como: "é muito trabalhoso", "estou acostumado no meu sistema". Os elementos de orienta ção, em sí abstratos, podem ser constatados nos argumentos abaixo.

Referindo-se ao plantio em conformidade com a técnica:

\footnotetext{
"... eu planto meio na cisma... assim meio no escuro..."

P. Por que?

R. "Porque tem que levantá cedo" (entr. $n^{8} 1$ ).
} 
"... eu ainda não aprovei a técnica, porque é muito trabalhosa" (entr. $n^{8} 7$ ).

"... a gente planta no meu sistema mesmo..."

$P$. Por que?

R. (faz uma pausa para responder) "... estou mais acostumado: (entr. $n^{8} 3$ ).

"... a gente vai levando assim no jeito da gen te mesmo".

P. Mas o senhor não acha que, usando a técnica, rende mais?

R. "rendê, rende, mas assim também dă" (entr. $n^{8} 101$.

Contudo, deve-se observar que as asserções colocadas não podem ser encaradas isoladamente em uma análise interpretativa. É preciso observar outros comportamentos manifestos, como a forma de conduzir a unidade de produção agri cola. 0 entrevistado $n^{8}$ i, por exemplo, cultiva fumo dentro de um padrão tecnológico, orientado por técnicos da souza Cruz. $0 n^{8} 7$ e $0 n^{8} 3$ cultivam frutas, cultura que exige uti lização de tecnologia moderna sob pena de não obter produção. Apenas o $n^{8} 4$ não emprega tecnologia moderna. Interessante é que os entrevistados $n^{8} \mathrm{~S} I, 7$ e 3 empregam tecnologia moderna apenas na nova linha de exploração: não a ut1l1zando nas cultivadas tradicionalmente. Essa condição expressa não uma opo sição à valores novos ou a novos instrumentos de produção, mas um redimensionamento nos padrães de conduta, onde o sistema 
de referência na manutenção da sua consistência, ora reflete valores tradicionais ora valores novos.

Os demais entrevistados, referindo-se à utiliza ção da tecnologia refletiram elementos de orientação relacio nados a objetos empíricos e sociais,constituintes da situação. De um modo geral, há um consenso em torno da necessidade de uso de meios tecnológicos para aumentar a produção. Tal fato é refletido mais especificamente na ärea de insumos modernos.

"... eu plantava no meu sistema, mas agora vou plantá na téerica; a terra é muito fraca, não da rendimento" (entr. $n^{8} 28$ ).

"... até agora deu sem a técnica, agora não tá dando mais"

"... eu quero plantá com a técnica" (entr. n'15)

"... quanto às lavouras plantadas com a técnica não tem nem comparação... o uso da técnica sempre recompensa, pois aumenta a produção... Na batatinha tem que pôr adubo, senão não dä" (entr. $n^{8}$ 19).

Todavia, o uso de tecnologia como meio de maxi mizar a gratificação em torno de interesses económicos é frequentemente racionalizado, tendo-se como base os condicionantes da situação. A racionalização do uso do adubo, por exem plo, está em função da expectativas que o ator forma em torno da gratificação que o objeto alternativo pode proporcionar. 
Quando um determinado produto possui preço instável ou muito baixo, o adubo é usado em quantidades inferiores ao recomenda do pela experimentação agrícola.

"... bem na téenica não dá pra arriscá né, por exemplo, no feijão eu ponho o adubo, mas está faltanio a cobertura... a despesa é muito gran de" (entr. 33).

"... aqui tudo deixou da tëcnica porque come muito adubo, que está muito caro" (entr. $n^{\circ} 20$ ). (referia-se a produção de milho).

"... o adubo, o calcário,...tudo é tão caro... e a gente não tira o que empata na planta". (entr. $n^{8}$ 25) (plantador de milino).

B uso moderado de tecnologia constitui produto de uma ação racional em que se considera os fatores condicionantes da situação, tais como: o preço de venda do produto, as condições de fertilidade do solo e o custo dos insumos. As sim, tendo em vista a baixa relação benefício/custo que poderia privar o ator de obter a gratificação conforme suas expectativas, a solução é encontrada na utilização do adubo em quantidades reduzidas. Segundo a perspectiva do ator, contudo, o adubo ainda contribui com o aumento de produção e da produtividade.

"... eu acho assim se a gente põe um pouco de adubo ele rende um pouco, mais rende né,...nem 
se planta assim "meio" (sem técnica)...ele sem pre dá né... Se plantasse a cebola sem adubo e la dava bem mais miüda né, e (se) o prego não ajuda, ai dá menos né... então se ela dá um pouco mais graúda rende mais..." (entr. $n^{9} 26$ ).

"... a análise da terra veio muito tarde, ai deixei pro ano, daì eu vou plantá com a téenica... a $\vec{\imath}$ eu vou plantá um pouco, pra plantá bas tante também não dá... o adubo no prego que es tá é meio caro né... No preso que está o adubo no final dá prejuizo... olha... o preso do saco de adubo está $C r \$ 200,00$ e de feijão $\operatorname{Cr} \$ 250,00$, e o servigo e a semente como fica?..."

"Assim a gente planta um pouco com o sistema da gente e um pouco dentro da técnica" lentr. $\left.n^{8} 16\right)$.

"... eu planto um pouco com a técnica um pouco com o meu sistema, se fosse pra plantä de acor do com a técnica... teria que plantá um pouco menos e gastá um pouco mais, mas talvez compensasse $n \vec{e}$... A $\vec{\imath}$ tem muita gente que está plon tando (na técnica), mas é pra semente né e está plantando bem na técnica... já tem preso ga rantido por cr\$400,00 o saco né, quer dizer, dai a pessoa tem vontade de trabalhá né... ago ra... (pensa) nós temos o prego meio baixo do feijão; se nós for levar tudo bem na técnica, no final não dá o Zucro... e que 'Deus o $i_{i-}$ vre' a gente ainda perde um pouco... esta chuva de verão" (entr. n? 23). 
Preço e mercado para os produtos são elementos de orientação relacionados a condicionantes situacionais, que têm contribuído para a não utilização de meios tecnológicos refletindo, em última instáncia, na mudança da linha de exploração.

"... de primeiro, nós plantava mais batata, tri go, milho e feijão, cebola não plantava... não tinha comércio. Batata, por mais barato que fôsse, ela saía, né, podia ter a quantia que quisesse e o trigo também, mas parou de dá. Ai larguemo a batata... quando ela dá, ela dáa, quando dá bem, bem no fim, não tem prego, a gen te tem que dá de grasa e o adubo é muito caro e esse (defensivo) para pulverizar... bem no fim a gente perde e perde um dinheiro grande do borso e servico... no final das contas, dá zero mata zero, o que faz, gasta e não pode ir prá frente... não sobra..." (entr. $n^{\circ} 22$ ).

"... o milho é uma cultura que ainda sai mais barato; a batatinha... não compensa plantá no preso que tá o adubo" (entr. $n^{8} 25$ ).

Com relação à diversificação de linhas de exploração dirigidas para o mercado, os elementos de orientação que determinam a escolha das alternativas refletem acentuadamente relações com objetos condicionantes, como preço do produto e perspectivas de mercado. Nos casos em que se tem oferecido novas alternativas de produção, não rouve resistência do ator para com objeto catético de orientação da ação. 
Este é o caso do fumo em expansão e da pecuária leiteira, assim como da fruticultura, objeto específico em análise.

A concretização das metas definidas anteriormente é somente possível com o ajuste dos objetos empiricos- meios de tal forma a satisfazer às expectativas. Não raras vezes, o ator é privado de obter a gratificação por ele esperada anteriormente. Gs depoimentos expressos abaixo refletem os vários elementos de orientação que se relacionam com a manutenção das diversas linhas de exploração.

"... é preciso plantá de tudo um pouco porque o preco das coisas um ano $\dot{e} u m$, um ano é outro e, assim, um contrabalanca o outro" (entr. $\left.n^{8} 7\right\}$.

"... a gente planta tudo porque dai um ou outro dá (uma ou outra planta dá rendimento). Se plantā só um daí pode não dä". (entr. $n^{8}$ I5).

"... planto diversas culturas prá equilizrá... se plantá uma só coisa e aquilo não dáa gente vai rio abaixo" (entr. $n^{8} 23$ ).

"... a gente tem que plantá de tudo um pouco, porque tem medo de plantá uma coisa sö e não vendê"?. (entr. $\left.n^{8} 6\right)$.

"... a gente não deixa de plantá as outras coi sas pelo seguinte: o preço é uma coisa que nin guém garante; então, a gente não pode plantar 
uma sö cultura... uma planta defende a outra né... por exemplo, a gente parte pro feijão e pra batata né e quando eu não posso contá com aquela mercadoria, a batatinha, então o feijão encobre né..." (entr. n² 27).

"... se o colono plantá só uma cultura, se ele trabalha com o banco vai entregá até o terreno e vai trabalhá de camarada; eu planto de tudo um pouquinho, 'pro gasto'. Mas o que eu planto mais é feijão... por mó da venda né ...a maior forsa eu planto o feijão. o senhor faca a conta: embora eu venda a Cr\$240,00 o meu pià mais velho (filino), está com 11 ano né $e$ eu tenho que pagá camarada, então eu empreito e pago... Has... o colono tem que joga com tudo porque se dá algum temporal perde tudo plan tando uma coisa só... e o prego da lavoura está fraco. O senhor veja vai vendè um saco de feijão está Cr\$240,00, não dá um saco de aqücar... O mitho estáa a Cr\$1,00 o kilo quando a gente compra, beneficiado está Cr\$ 4,00. A mercadoria não tem valor na mão do colono, depois que ele vendeu e vai comprá já dobra... quer dize pro colono está fraco... E que varia o preso das lavouras então a gente tem que jogá com tudo... O governo devia fazê um negócio devia fixá o prego; o senhor aí ia plantá e ia sabê quanto que ia vendê, então o senhor fazia idéia, o preso é esse, vou plantá isso aqui, vai me dá mais do que aquele, mas então como vai o prego então tem que jogá porque não dá pra se fiá naquito". (entr. nं 3I). 
.84.

As diversas alternativas,são eleitas diante das condições que o ator visualiza, conforme o preço do produto, conforme as condições climáticas, fertilidade e topografia do solo, perspectivas de mercado, recursos financeiros e mão-de-obra. A manutenção de diversas linhas de exploração dirigi das para o mercado, além daquelas destinadas ao auto-abasteci mento, é, antes de tudo, produto de uma racionalidade em que a meta básica do produtor deve ser atingida: a sua manutenção e da família.

A instabilidade de preço e oscilações de merca do para os produtos atenuam a ação de elementos sociais que estão à disposição do ator para orientá-los quanto ao uso de objetos-meios. Tal ocorre com a atividade do agente de extenção rural, que oficialmente desempenha o papel de orienta dor técnico. Ele é visto, com reservas, em diversas situações, prejudicando o seu trabalho.

o depoimento abaixo vem refletir claramente tal problemätica.

"... tem muita gente que quando o agrônomo vai em casa, não dă nem confiança porque quer vendê o dele... estão em convênio com o governo" (entr. ${ }^{8}$ 19).

A análise interpretativa efetuada mostra que a utilização de qualquer objeto-meio se efetiva com vistas ao atingimento das metas estabelecidas pelo ator. A utilizaçäo 
desses objetos-meio, no entanto, é efetuado a luz de um siste ma de orientação no qual são contemplados elementos subjetivos e empíricos. Tais elementos fazem parte de um processo de racionalização que reflete a consideração de vários objetos da situação num esforço de, com o uso de meios,atingir me tas. A utilização de uma ou outra alternativa, ou o uso de um ou outromeio, en maior ou menor grau,constitui o resultado de uma racionalidade ou de um processo de adaptação aos condicionantes da situação.

\subsection{Função latência}

A motivação para o desempenho do papel de produzir, ou para a escolha de uma ou outra alternativa, é obtida fundamentalmente na gratificação de caráter econômico. Um maior rendimento em termos monetários implica em um maior grau de motivação para a ampliação da área produtiva com as culturas de boas perspectivas de comercialização. Isso demons tra que, na atividade ocupacional, os valores que movem os atores estão em sintonia com valores societários.

"... cada um se interessa de plantā e vendê, mas quando ele colhê (o colono) o feijão que está láa estocado no paiol, o problema é o preso né, dai, - cara diz, bem esse ano que o feijão está láa eu não vendi e eu não sei se vou plantá mais porque taí no paiol não posso vendê. Eu vendo mas não me cobre a despesa que fiz...então não 
.86.

sei onde que está a falha. Porque interesse eu acho que cada um tem né,... porque pode apare cer falha né, mas não, todos os anos cada um fica satisfeito quando dá certo; dai tem a coragem de aumentar e plantá direito. Mas se ele plantá direito na técnica... faz uma despesa de $\operatorname{Cr} \$ 20,00, n \bar{e}_{s}$ dai ele colhe aquele feijão e dai faz uma despesa de $\operatorname{Cr} \$ 20,00$ ne, dai ele colhe aquele feijão e dai faz aquele levan tamento; é Cr\$20.000,00 que empatei e minha planta só dä tanto. Dai ele vai dizer bom eu arrisquei sö pra ganhá aquela parte né... se ele gasta Cr\$20.000,00 e ganha Cr\$40.000,00 ou Cr\$50.000,00 ai tem aquela coragem né". (entr. 27).

Percebe-se assim que a roalização das metas conforme expectativas do ator näo somente é o aspecto gratifi cante da ação, mas ao mesmo tempo, motiva as suas açöes futuras. Somente a realização das metas em maior ou menor grau justifica a utilização contínua de determinados meios comprovados em sua eficácia.

\subsection{A Fruticultura como nova alternativa}

Os Empresários Familiares entrevistados sobre a fruticultura como objeto-meio, condicionaram a sua utiliza ção a elementos de orientação de natureza empírica como se vê em seguida:

".. o maior problema é a venda... se eu tives 
.87.

se onde vendê plantava mais frutas"(entr.n"7).

"... muita gente quer plantá frutas, mas tem pouco terreno". (entr. n $\left.{ }^{8} 11\right)$.

"... se eu tivesse certeza na comercializacão de frutas, eu aumentava o plantio". (entr. n'21).

".. eu estava com vontade de plantá, mas o terreno é muito longe né". (entr. $n^{8} 21$ ).

"assim, eu vejo faláa tendo pêssego bastante não tem pra quem vendê, dai..." (entr. n' 28).

"... pois, se fosse só entregá na fábrica ou em algum lugar certo, ai muita gente plantava... até eu plantava... mas assim... agora, sai de casa em casa, a gente perde tempo e no fim ainda não vende..." (entr. $n^{8} 31$ ).

O ator percebe uma condição de extrema incerteza quanto à concretização de sua meta com a exploração da fruticultura,permanecendo em estudo de expectativa. Não obstante, os Empresários Familiares, que já fizeram da Fruticultura uma atividade orientada para o mercado sentem-se gratifi cados a ponto dos resultados obtidos motivarem o aumento da ärea de plantio de frutas.

Os índices de produção alcançados pelos prime $\underline{i}$ ros fruticultores indicam uma tendência de saturação de merca do local e os demais atores estão conscientes disso. 
.88.

o mercado intermunicipal só é acessivel aos que possuem meio de transporte e experiéncia em comercialização, situação essa não comum entre os atores.

Em razão dessa limitação dos objetos condicionantes, o ator passa a não efetivar a fruticultura como ativi dade. uma vez que percebe que poderä não lhe proporcionar os resultados esperados. Opta, então, por alternativas que lhe garantam realizaçāo.

"... o agricultor está pensando... não sabe se planta ou não planta; está meio duvidoso; não sabe se vai dá uma boa renda ou não vai... por que o feijão, milho... um pouco ele vende, barato mais vende, agora frutas..." (entr. $n^{\circ} 28$ ).

Esse estado de expectativa é refletido nos depoimentos de entrevistados que se véem limitados por fatores relacionados à àrea de terra para plantio, por uma estrutura de comercialização inadequada e pelos meios deficientes de transportes. Mesmo aqueles que já são fruticultores mantém-se em estado de alerta.

"Planta-se mais frutas, desde que tenha mercado garantido" (entr. $n^{Q}$ I).

"... estou esperando prá vê o resultado da ven da... o cara (agricultor) quer plantá, mas não sabe se planta, não sabe se vai dá resultado... Está no escuro, então ele espera o outro plan$t \bar{a}$, prá vê, se dâa ou não dá... Eu planto ou- 
tras coisas porque não posso ficar só esperando" (entr. n? 3 ).

"... se tivesse colocacão por um pręo fixo, daria prá plantá frutas, mas assim, não sei se vou ganhar, se vou perder..."

$P$. D senhor, então, não pretende plantar mais frutas?

R. "Plantar mais frutas pra quê? Pra apodrecer?... O problema maior $\vec{e}$ que não tem quem compre,... este é o problema do colono.... se eu tivesse onde vender, eu plantava frutas" (entr. $n^{\circ} 9$ ).

"... conforme o mercado, comparando com a verdura, tem dias que vai acontecê conforme o fru ticultor carrega no seu carro, aquela mercadoria, aquela fruta e vai vendê e chega ao merca do e ninguém qué, porque está lotado né... Agora, se fösse por exemplo em Irati.... se fôsse feito uma fảbrica de doce,... se a cooperativa ligasse com outra e colocasse láa e colocasse de dois, três dias a venda, dai sim" (entr. $n^{8} \quad 27$ l.

Prevista a saturação de mercado local, é sugerida e aguardada a instalação de indústria ou de uma organização cooperativista que venha atender interesses de categoria. A realidade demonstra, pois que uma estrutura de comercialização com mercado e preço assegurado transformariam a agricultura da região emi sua organização produtiva. Sob condi çöes de certeza, existem até aqueles que se especializariam 
exclusivamente no cultivo de frutas.

"... a gente primeiro quer estar na certeza que o negócio das frutas vai pra diante; se a gente vê que pode ficar na fiüza daquizo (fruticultural, então a gente abandona tudo isso e Iuta com aquilo... Se tivesse garantia a gente larga de plantá outras coisas e planta frutas $e$ dai tem mais gente que vai plantá porque tem muita gente que está querendo ter certeza né?" (entr. $n^{8}$ E).

"No caso da mą̧ã, como se fala, até compensaria lidar só com a maçã e deixar de plantar as outras culturas" (entr. $n^{9} 2$ ).

Apesar da fruticultura constituir uma linha de exploração,que utiliza práticas agrícolas complexas e que exí ge necessariamente o uso de tecnologia moderna, não se constatou casos em que tais fatores influissem negativamente quan to à sua utilização como objeto-meio, por parte dos Empresá rios Familiares que têm por meta o mercado.

- empenho do ator para conhecer melhor os aspectos técnicos da fruticultura denota uma disposição no sentido de explorá-la com maior eficiência e maximizar gratificaçōes.

"... se tivesse colocaç̃o certa, o pessoal entraria bastante na fruticultura, mesmo tendo que levá na técnica... nossa... não importa në... $\vec{e}$ sö pegá e dizê olha tem que fazêe assim... Eu 
também estou fazendo assim meio no escuro, que eu não tenho explicacão boa... como colocáa o adubo, poda verde..." (entr. $n^{8} 23$ ).

"... o pessoal seguiria orientação técnica, se fosse bem orientado... comparando que nem aqui na comunidade só eu estou plantando... então com uma orientą̧ão certa, bem certinho, que eles reparem como é que é o serviço como é tudo, cada um se interessa, né, mas tem que ter orientagão, porque eu acho que tem que ficáa uma pessoa que saiba né... lidar com frutas... ai todo mundo se interessa" (entr. $n^{8} 23$ ).

Não obstante, como nova alternativa, a fruticul tura, denota nos casos em que já se consolidou como meio,con tituir uma atividade com características operatórias perfeita mente ajustáveis aos padröes relacionados à atividade ocupacional, encontrando, dessa forma, receptividade no sistema re ferencial dos atores.

No que se refere ao aspecto catético do objeto observa-se um envolvimento no sentido de obtenção de gratificação, não somente de carāter econōmico, mas também afetivo.

"... eu preferia lidar com frutas, do que com outras coisas" (entr. $n^{8} 23$ ).

"... é tão bom lidar com frutas e, depois, quando comega a flori... fica bonito e vem as frutas..." (entr. $\left.n^{8} 6\right)$. 
o envolvimento do ator com o objeto ocorre de forma tríplice, isto é, catéticamente, cognoscitivamente e avaliativamente. Os aspectos catéticos e cognitivo integram elementos de orientação relacionados a outras alternativas da situação num processo avaliativo, recaindo em ültima instància na eleição de alternativas.

Quanto ao crédito rural,que visa dotar o agricultor de recursos financeiros para a implantação da atividade, apenas quatro deles utilizaram. Preferem trabalhar com capital próprio. o crédito rural orientado,que normalmente exige um projeto superior a um hectare, é visto com reservas pela maioria dos agricultores dado a incerteza de comercializar o produto, em razão de experiências obtidas com outras culturas de preços instáveis. Aquí o uso do crédito também faz parte de um processo racional, em que o ator visa assegurar sua meta, quando não suas próprias bases existênciais. Segundo sua concepção:

"... nessa base o governo quer acabar como o colono com o valor que ele está dando... Se o colono plantá só uma cultura, se ele trabalha com o banco vai entregá até o terreno e vai tra balhă de camarada" (entr. n8 31 ).

o crédito só é utilizado em pequena escala, refletindo um processo de adaptação às condições, tais como a própria fruticultura, que lentamente começa a ocupar espaço em sua propriedade. Inicialmente, planta-se alguns pés para 
preservar-se contra possīveis frutrações. Quando se percebe a possibilidade de se obter a gratificação almejada, lentamen te, amplia-se a área dessa cultura.

\subsubsection{Significado da Fruticultura para os produtores rurais}

O conceito de relevància, neste trabalho,expri me um estado de motivação ou predisposição do ator em utilizar o objeto-meio. Resulta de um processo subjetivo, que se dá à luz de padrões institucionalizados, definidos por elementos de orientação motivacional e elementos de orientação valorativa. E, porém, na relação com a situação que o ator mantém contato com as propriedades dos vários objetos constituintes e chega a definir-se, motivacionalmente, em favor da utilização do objeto. Esta definição motivacional, de um lado, depende das propriedades que são encontradas no objeto e dos resultados que esse mesmo objeto (fruticultura) pode propor cionar, e, de outro, dá orientação da ação que é organizada sobre marcos normativos, com propósitos definidos. Num proces so final de definição, em torno da utilização de um objeto-meio, a predisposição ou motivação, que define o interesse do ator, deve estar em consonáncia com os resultados que o objeto pode oferecer.

o ator pode estar predisposto a utilizar o obje to com vistas a determinados interesses. Porém, a ação não se 
efetiva em razão dele perceber que objetos empíricos condicionantes da situação podem levá-lo a uma frustação.

A releváncia do objeto fruticultura pode ser constatada através das diversas asserções colocadas, e da ana lise sistemática efetuada anteriormente.

Em todos os cásos, que se manteve contato, ja havia uma definição em torno do objeto, isto é, uma condição de releváncia ou irrelevància.

Conforme a conceituação no capitulo III, a condição de relevância está relacionada a uma disposição em cultivar frutas, com vistas a obtenção de uma maior rentabilidade, isto é,como uma linha de produção orientada para o mercado. A condição de irrelevãncia diz respeito a uma definição não favorável à utilização do objeto diante de outras alternativas, ou de uma exploração com vistas apenas ao consumo próprio, sem interesses comerciais.

Baseado nisto constatou-se que, dos atores cate gorizados como Empresários Familiares, apenas um mantém o obje to em condição de irreleváncia e exerce atividade paralela à agricultura, mesmo sendo agricultor tradicional. A não relevância da fruticultura é atribuída à relevância de outra atividade que desempenha atualmente: a atividade de transporte.

Em função das metas estabelecidas, os produto res buscam os meios mais eficientes para ating $\bar{i}-1 a s .0$ instru mento capaz de proporcionar um maior rendimento é o que tem 
.95.

prioridade na unidade de produção. Isto demonstra que a ação produtiva está mais orientada por padrões de "desempenho" do que por padrões de "qualidade". Não significa que o envolvimento do produtor com os instrumentos-meios näo tenha qualquer relação com os aspectos qualitativos desses instrumentos. No que se refere à fruticultura,pode-se afirmar que o produtor avalia a alternativa muito mais pelo que ela pode oferecer em termos de seu desempenho, do que pelo que ela é como atividade. A complexidade da exploração não chega a ser considerada como obstáculo para sua implantação.

o paràmetro "rentabilidade" constitui um crité rio universal que impera na escolha das alternativas de explo raçäo. A Fruticultura ofereceu e oferece algumas perspectivas e por isso teve a preferência do produtor. Os depoimentos mostram que uma cultura torna-se mais importante quando é mais rentável economicamente, o que indica haver tendência para es te parámetro se consolidar como critério universal de escoIha de alternativas de produção,embora outros fatores particu lares possam ser considerados.

Em razão dos ideais económicos, que imperam na atividade produtiva: há uma tendéncia de prevalecer padrões instrumentais sobre os expressivos. A persistência de meios tradicionais que poderia refletir uma orientação expressiva constitue uma resultante de uma impossibilidade de substituir o uso de instrumentais. A substituição de meios tradicionais 
por modernos poderia não proporcionar a realização económica do ator. Nesse sentido a aparente contradição de padrões (tra dicionais e modernosl de orientação, na realidade, ajusta-se, permitindo a manutenção do equilíbrio do sistema de ação da categoria de produtores.

\subsubsection{Fatores condicionantes relacionados com a con- solidação da atividade Fruticultura}

A análise dos elementos que orientam a categoria Empresário Familiar na utilização da fruticultura, demonstra que a reorganização do sistema de produção agrícola se ve rifica diante de um ajuste à elementos básicos que se relacio nam diretamente com os resultados económicos proporcionados pelo instrumento. Estes elementos básicos, que compõem um sistema de referéncia de ação do ator, orientando-os na escoina de alternativas de produção são os seguintes:

a) Comercialização - Se define como elementos de orientação, que o ator designa de "colocação para o produ to", "comércio", "consumo", "prego", "venda". São justamente os vários aspectos da comercialização, como o preço, o mercado para os produtos, a quantidade consumida, que dimensionam o grau de satisfação pela utilização do instrumento.

b) Área de terra - Este fator, embora não se tenha demonstrado, para o caso, de todo limitante ou restriti 
vo, não permite o cultivo de frutas em determinadas circunstàncias, quer seja em razão das características pedológicas, quer seja dado a disponibilidade de área própria cultivável. A categoria de produtor de maior releváncia neste trabalho - Empresário Familiar - desenvólve atividades em áreas próprias mas de tamanhos diversos e a utilização de cada área é racionalizada conforme as metas estabelecidas por seus representan tes. Assim, em primeiro plano está a garantia da própria sobrevivência e, nesse sentido, as culturas consideradas tradicionais possibilitam ao ator e a sua família satisfazer necessidades básicas com maior grau de segurança.

c) Culturas alternativas - As culturas de ciclo anual, além de constituirem produtos de auto consumo, têm mercado assegurado e prioridade na atividade agrícola, por atender necessidades básicas de alimentação e por proporcionar excedentes comercializáveis, que permitem a troca de produtos complementares. A ocupação da ärea se dá pelas culturas de ciclo anual, de preferência com aquelas que podem ser aproveitadas para consumo próprio, depois com aquelas que têm mais chance no mercado. Assim, a fruticultura aparece quando se dispõe de área que ultrapassa os limites necessários à pro dução de autoconsumo e de uma produção que assegure um mínimo comercializável.

d) Transporte da produção - Em determinadas si tuações, o fator transporte, quando carente, é suprido atra- 
vés de fretes pagos a terceiros, o que além de afetar graus de satisfação, favorece categorias que possuem os meios de transporte. Assim na medida que o mercado local apresenta in dices de saturação, a situação tende a beneficiar os que tem meios de atingir mercados intermunicipais. Com freqüència sur gem, também, intermediários locais, devidamente motorizados, que se encarregam de transportar e de comercializar o prodü to.

e) Recursos financeiros - Se, por um lado, este fator tem se manifestado carente, por outro, embora haja linhas de crédito para a fruticultura, há certo receio em sua utilização. Esta atitude se constata principalmente entre aque les atores que têm poucos recursos materiais para oferecer co mo garantia de empréstimo. o fator está ainda relacionado à própria incerteza quanto ao destino da produção,diante da ine xistência de infraestrutura adequadas ao seu escoamento.

A eleição da fruticultura como atividade está, pois, sob a orientação de condicionantes que são representados pela comercialização, transporte, área de terra, culturas alternativas e recursos financeiros, que dimensionam o grau de sua utilização em consonància com os propósitos estabelecidos pelos atores. Maior àrea de frutíferas se encontra quando tais condicionantes asseguram a concretização da meta. Assim como os outros meios na atividade agrícola, a fruticultura se efetiva como um instrumento de realização do ator, 
quando atinge os resultados esperados. O que se verifica é uma expectativa, não em torno das propriedades intrínsecas ou atributos do objeto, mas em torno do que o objeto meio pode oferecer para se alcançar os fins almejados. A despeito de que qualquer fator inerente ac objeto possa ter influência ne gativa na sua utilização, dadas as alterações nos padrões de conduta do ator, ele é suscetível de ser superado, através de reajustes, sempre que os alvos são visualizados com relativa segurança. Há um esforço do ator ao envolver-se com o objeto, quando este se demonstra eficiente.

A alternativa não constitui produto de primeira ordem no atendimento às metas finais,considerando as características da cultura, tais como: (a) produção económica somente aos 3 ou 4 anos; e (b) necessidade de comercialização do produto logo após colheita, em razão da falta de siste mas de conservação de armazenamento adequados.

Referindo-se ao sistema de personalidade em sua perspectiva externa, verifica-se que o ator está motivado ou predisposto a orientar sua produção, visando a obtenção de resultados económicos, através da fruticultura. Nesse sentido, sua açäo na atividade económica ou ocupacional está em consonáncia com valores do sistema global, que tem a economia de mercado como base de integração.

Porém, embora os atores em sua função integrativa motivem-se a buscar metas de conteúdo valorativo segundo a prescrição de um papel, que se define organizacionalmente, 
através da produção voltada para o mercado; este, mediante seus componentes empíricos, não thes assegura indices de gratificação suficientes para lhes garantir a subsistència e permitir uma integração vital do sistema social em novas bases organizacionais. Daí porque a fruticultura é utilizada com cau tela. Ao se lançar em novas alternativas que possam trazer alguma recompensa de ordem económica, através da produção orientada para o mercado, como a fruticultura, o ator coloca em jogo a sua própria subsistència, que é assegurada com culturas tradicionais.

É através da exploração de culturas de subsis tência e de culturas orientadas ao mercado que o sistema de ação do produtor pode se manter e se ajustar parcialmente aos requisitos de inserção na sociedade. Embora os meios tradicionais de produção não sejam uma condição inerente a padrões e valores tradicionais do Empresário Familiar eles tendem a se manter no sistema de ação. A medida que determinados elementos empíricos condicionam a ação dos atores, de forma repetitiva,impedindo-os de sua realização, os instrumentos tradicionais passam a ser retomados, constituindo uma constante, ou um padrão de orientação da ação.

Assim,a utilização de meios tradicionais de pro dução na ocupação agrícola não tem a ver apenas com um desinteresse ou rejeição do produtor a meios novos,mas com a histó ría de sua relação com a situação. 


\subsection{Resultados obtidos pelo projeto e conseqüências da} atividade Fruticultura para as categorias de produ tores envolvidas. Verificação da hipötese básica.

Constatado que, no setor rural, os fatores situacionais relacionados com a utilização da fruticultura,como instrumento-meio, dimensionam o grau de sua utilização,necessário se faz analisar comparativamente os resultados obtidos pelo projeto, em cada categoria.

Tem-se neste estudo apenas uma categoria perti nente ao setor rural, - o Empresário Familiar. A outra catego ria,embora não constituída por produtores genuinamente agríco las é relevada em termos analíticos, neste segmento,em razão de seu envolvimento com a fruticultura e da sua representatividade na amostra. E a categoria dos fruticultores Parciais. Por categoria de atores o "Projeto Fruticultura" obteve resultados conforme mostra a Tabela 10.

Tabela 10 - Frutiferas plantadas em Irat1, segundo a Categoria de Produtores.

\begin{tabular}{clcrrrrrr}
\hline & & \multicolumn{7}{c}{$N^{8}$ DE PÉS PLANTADOS } \\
\cline { 3 - 8 } CATEGORIA & ESPÉCIE & & 1973 & 1974 & 1975 & 1976 & 1977 & TOTAL \\
\hline \multirow{2}{*}{ EMPRESARIO } & Péssego & 1.527 & 100 & 649 & 385 & 75 & 2.736 \\
FAMILIAR & Maçã & \multicolumn{1}{c}{171} & - & - & - & 80 & 11 & 293 \\
& TOTAL & 1.698 & 100 & 680 & 695 & 1.216 & 4.389 \\
\hline \multirow{2}{*}{ FRUTICULTORES } & Péssego & 3.321 & 1.670 & 14.170 & 416 & - & 19.577 \\
PARCIAIS & Ameixa & 340 & 285 & 140 & 30 & - & 795 \\
& Maçã & - & 60 & 4.600 & 340 & 98.780 & 103.780 \\
\hline & TOTAL & 3.661 & 2.015 & 18.910 & 786 & 98.780 & 124.152 \\
\hline
\end{tabular}


A tabela 10 mostra que há maior nümero de frutíferas explorado pela categoria fruticultores parciais, do que pela de Empresário Familiar.

Considerando a relação existente entre a utili zaçäo do instrumento fruticultura e os condicionantes situacionais demonstrados no segmento 5.5.2., temos que: o fator "área da propriedade restringe a prática da fruticultura entre os produtores proprietários de pequenas áreas, que necessitam de uma policultura para a sua própria seguranga e subsis tência".

o fator comercialização, através de seus elementos infraestruturais, conforme a análise dos componentes si tuacionais realizada no segmento 4.2 .1 ., demonstram näo existir na situação. A análise de mercado indica maiores perspectivas para a cultura da maçã. A situação de mercado para a maçã é refletida na expansão da cultura, que é notória nos últimos anos, concentrando-se, todavia,na categoria fruticulto res Parciais. Em contraposição, as espécies pêssego e ameixa tendem a ser menos cultivadas pelas duas categorias em função da limitação de mercado, que caminha para a saturação a nível de localidade. Sumente aqueles que possuem meios de transpor te prōprios é que conseguem atingir mercados regionais e, as sim, tendem a ser beneficiados.

Um dos fatores que mais tem contribuido no dimensionamento do quadro fruticola local relaciona-se com a disponibilidade de recursos financeiros. 
De um lado, o custo de implantação do empreendimento exige um capital de exploração; de outro, o período para obtenção de retornos do capital empregado situa-se na faixa de 3 a 4 anos, ressalvando a ocorrēncia de fenómenos climáticos adversos à cultura. Se agregarmos a essa questão a inexistência de infraestrutura para escoamento da produção, é possível compreender a percepção do agricultor sobre o risco e a insegurança que o empreendimento oferece, principalmen te, para a categoria Empresário Familiar.

A categoria Fruticultores Parciais, na prática de outras atividades que não a agricultura, são as que correm menor risco com a fruticultura, uma vez que é a ocupaçāo não agrícola a base produtiva de seu meio de vida. Se qualquer fä tor relacionado à fruticultura pode afetar a situação econômi ca dos que a produzem, com certeza não afetará significativa mente a estabilidade económica dos fruticultores Parciais. Por outro lado, pode afetor o precário equilírio daqueles que dependem diretamente da produção agrícola e que reservam e ocupam parte da área agricultável com fruticultura, quando po deriam explorar outras alternativas de ciclo anual. Nesse sen tido, há maior segurança para os fruticultores parciais e maior risco para a categoria Empresário Familiar. Mesmo assim pode-se observar prudéncia por parte da Categoria Fruticultores Parciais ao optar pela Fruticultura.

Se tomarmos o crédito rural, como sendo um dos instrumentos que visa suprir a deficiência de capital, verifi 


$$
.104 .
$$

ca-se que ele é pouco utilizado,pelas mesmas condições de insegurança já demonstradas anteriormente. Apenas um Empresário Capitalista e três Empresários Familiares fizeram uso de tal recurso.

A Tabela 10 mostra um expressivo plantio de pêssego e maçã em 1975 e 1977, respectivamente. Esses nümeros referem-se praticamente a dois fruticultores que se valeram da utilização de recursos oriundos de incentivos fiscais. Obser va-se no Anexo 2 que os entrevistados $n^{9} 61$ e 62 cultivam 13.940 pés de pẽssego e 98.000 pËs de maçã, respectivamente. Somente estas duas unidades de produção representam $87 \%$ da fruticultura local. Referem-se à categoria de fruticultores Parciais.

A não utilização de recursos fiscais pela cate goria Empresário Familiar deve-se às restriçōes impostas pela própria legislação, que regulamenta a utilização de incentivos. O plantio mínimo de uma área, com 10.000 pés, estabelecido inicialmente pela Lei 5.105 de $02 / 11 / 76$, e, após, de uma área de 50 ha contíguos, pelo Decreto Lei 1.376 de $12 / 12 / 74$, elimina qualquer possibilidade das categorias com disponibili dade de área cultivável inferior a 50 ha a se beneficiarem de tal instrumento. Com a promulgação dos Decretos Leis 1134 de $04 / 11 / 70$ e 1376 de $12 / 12 / 74$, fica eliminada qualquer possi bilidade da pessoa física valer-se desses benefícios.

A legislaçäo é, pois, descriminatória, uma vez que, pelas condições que impõe, favorece apenas catagorias 
.105 .

produtoras näo muito comuns ao setor agrícola da economia, í to é, pessoas jurídicas.

A utilização de recursos fiscais, na forma regü lamentada, demonstrou-se funcional às categorias fruticultores Parciais embora a legislação alterasse anualmente a par cela dedutivel do imposto de renda. A partir de 1978 apenas $25 \%$ do imposto devido pode ser aplicado em empreendimentos com exploração de frutíferas.

0 custo elevado de implantação da cultura é atenuado por recursos do incentivo fiscal apenas para os fruticultores parciais. Em consequéncia esta categoria terá maio res condições de resolver os aspectos relacionados à comer cialização, considerando o seu maior acesso a recursos financeiros, que se farão necessários à organização de infraestrutura bäsica, destinada ao tratamento, classificação, e condicionamento, armazenamento e transporte de frutíferas. A maior experiência organizacional e administrativa,aliada ao poten cial de mercado existente, com certeza, também tenderá a bene ficià-los.

Se analisarmos a questão, concomitantemente, na perspectiva dos interesses da sociedade e de uma das próprias metas do Projeto Fruticultura (diminuir importaçōes), verifi ca-se que tal instrumento tem sido altamente eficiente. Basta que se observe os dados correspondentes aos projetos aprova dos pelo Instituto Brasileiro de Desenvolvimento Florestal (IBDF) nos estados do Paraná, Santa Catarina, Rio Grande do 
Sul e São Paulo (Tabela ll).

Tabela 11 - Projetos de Fruticultura aprovados pelo IBDF-Período 1967 a 1977 .

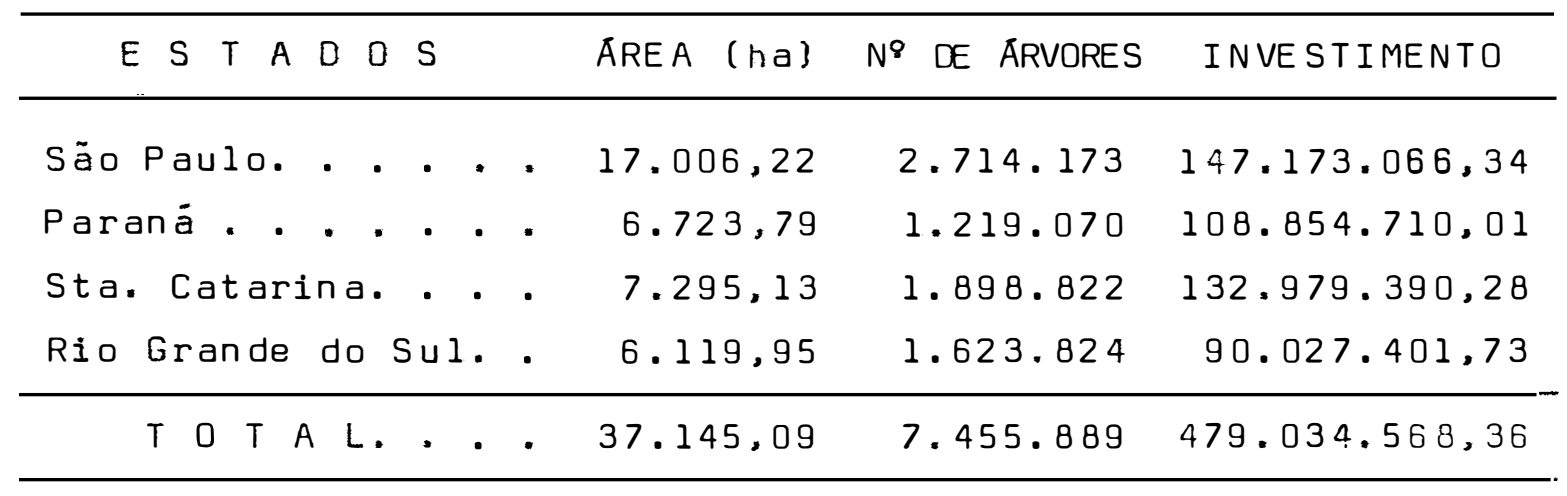

FONTE : IBOF - SC $(1978)$.

Tabela 12 - Projetos de Fruticultura aprovados pelo IBDF no Estado do Paraná, por culturas - Período 1967 a 1977.

\begin{tabular}{|c|c|c|c|c|c|c|c|c|c|c|}
\hline$E S P$ & & 0 & : & & E & $S$ & & ÁREA (ha) & $N^{8}$ DE ARVORES & INVEST I MENTO \\
\hline Maçã. & - & . & . & - & - & - & - & 735,25 & 644.241 & $35.423 .933,94$ \\
\hline Nöz Pecar & & - & . & - & $\bullet$ & . & - & $5.575,54$ & 488.329 & 68.838 .057 .09 \\
\hline Citrus. & . & . & . & - & : & . & - & 363,00 & 72.600 & 2.860 .716 .98 \\
\hline Pêssego & - & - & - & - & - & . & . & 50,00 & 13.900 & $1.732 .002,00$ \\
\hline 0 & $T$ & A & $\mathrm{L}$ & $\bullet$ & • & . & . & 6.723 .79 & 1.219 .070 & 108.854 .710 .01 \\
\hline
\end{tabular}

FONTE: IBDF - SC $(1978)$.

Embora os dados da Tabela ll näo permitam distinguir o montante aplicado especificamente em frutíferas de clima temperado, dimensionam o montante investido em empreen 
dimentos fruticolas independentemente de sua espécie. No perído 1967 a 1977 foram aplicados nos estados do sul Cr\$479.034.568,36, correspondente ao plantio de 7.455.889 är vores frutiferas.

Já a Tabela 12, que se refere à aplicação de recursos no Estado do Paraná, permite determinar o número de pés plantados de maçã e pèssego. O montante de 644.241 pés de maçã. segundo os dados de produtividade da cultura (Tabela l) corresponde a uma obtenção de produção média anual de 14.099 toneladas.

$$
\text { O montante em recursos fiscais aplicados na }
$$

Fruticultura, via Fruticultores Parciais, reflete uma incoerência do projeto, se o encararmos como instrumento que visa ajustar söcio-economicamente categorias de produtores de forma indiscriminada. Se nos reportarmos aos fatores básicos, que condicionam a redefinição do sistema de produção da categoria Empresário Familiar, verifica-se que é na carência de capital, que reside um dos problemas fundamentais.

Porém, se considerarmos, de um lado, o volume importado de maçã, e de outro, a produção que se obtém dos projetos já aprovados e executados com recursos de incentivos fiscais, observa-se que os resultados obtidos atestam a funcionalidade do projeto para a sociedade, de forma eficiente, na versão ora estabelecida. Esses resultados,por sua vez, também se relacionam a uma funcionalidade da atividade fruticultura para a categoria Fruticultores parciais, que respondem 
.108.

às necessidades de produção de forma rápida, através de empreendimentos em grande escala. A fruticultura, então, simul taneamente, demonstra-se funcional como projeto para a sociedade e como atividade para a categoria Fruticultores Parciais. No que se refere a categoria Empresário Familiar näo se pode afirmar com a análise presente que a ativida de demonstra-se disfuncional para esta categoria, uma vez que a fruticultura é apenas praticada em termos limitados. Contu do, pode-se inferir, que, mediante seus instrumentos de inter vençäo, a fruticultura demonstra-se mais funcional para a categoria Fruticultores Parciais, do que para a categoria Empresário Familiar.

A fruticultura demonstra-se mais funcional para a categoria do setor não agrícola do que para a categoria do setor agrícola. Esta constatação, por sua vez, se conside rada a expansão da atividade na forma presente, através da categoria Fruticultores Parciais permite concluir que a Fruti cultura tende a não se concretizar como instrumento eficiente de ajuste sócioeconômico da categoria Empresário Familiar.

A expansão da fruticultura em grande escala, mesmo satisfazendo necessidades da sociedade, revela um monopólio da atividade pela categoria Fruticultores parciais, que, concomitantemente, levará a outra categoria a se retrair da atividade .

E importante salientar que o retraimento da ca 
.109.

tegoria Empresário Familiar ocorre não por esta categoria irrelevar a fruticultura como atividade agrícola, mas, em razão da imposição restritiva dos condicionantes.

Cabe finalmente assinalar a reformulação par-

cial da hipótese básica deste trabalho. Conclui-se,nesse sen tido, que como projeto, a fruticultura demonstra-se funcional para a sociedade e, como atividade, mostra-se mais funcional para a categoria de Fruticultores Parciais do que para a cate goria Empresário Familiar, tendendo a gerar um desajuste sócio-econômico do sistema rúral. 
.110.

\section{CONCLUSÖES}

o projeto Fruticultura vem atingindo as metas de aumentar a produção para abastecer o mercado interno e reduzir o volume de importações. Este estudo, ao analisar aspectos näo explícitos do projeto, mostra como isto vem se realizando. Identifica, também, duas categorias básicas de produtores, envolvidos no projeto - Empresário Familiar e Fru ticultores Parciais - e esclarece o "sistema referencial de açãoi dos Empresários Familiares.

No papel de Produtor Rural, o Empresário Familiar destaca duas metas básicas: a maximização da produção orientada para o mercado buscando realização económica e a má nutenção de linhas de exploração voltadas para o auto-consumo, visando o sustento da família. Com essas duas metas os 
atores manipulam os meios sob seu controle de modo a concre tizar da melhor forma seus objetivos.

A adoção da fruticultura ocorreu sempre que as condiçöes situacionais favoreceram os resultados esperados pelo ator,sendo mais importantes os aspectos relativos à comercialização, área da propriedade, outras alternativas de ex ploração, recursos financeiros e transporte.

Os fatores relacionados à comercialização do produto que se refletem diretamente nas gratificações do ator, são os que mais se destacam. Constata-se uma lenta e gradual adoção da fruticultura como atividade-meio. Lenta,não em opo sição a valores de uma economia de mercado, mas porque os con dicionantes situacionais em que age o produtor não estão ajus tados para gratificar a utilização do objeto em maior escala.

A gratificação econômica é uma das metas do Em presário Familiar mas a incerteza de obté-la leva-o escolher meios alternativos, de forma que os resultados não sejam frustrantes e näo venham comprometer a integração dos vários com ponentes do sistema de ação da categoria. Assim, as diversas linhas tradicionais de exploração, aliados ao uso moderado de modernas técnicas agrícolas, tem sido uma estratégia capaz de oferecer recompensas e ao mesmo tempo manter equilibrado o sistema de ação do produtor.

Em sua dimensão interna, o sistema de ação atende os requisitos funcionais básicos, através da conjugação de meios novos e tradicionais, que permitem externamente aten 
der aos reclamos de inserção na sociedade. A dicotomia novo-tradicional, aparentemente contraditória, encontra sua razão de permanência na manutenção do sistema de ação do Empresário familiar. A fruticultura orientada para o mercado, faz parte do novo, e no grau em que é praticada atende aos requisitos funcionals do sistema de ação.

Nos estreitos limites cultivados, a fruticultura é percebida como funcional pelo Empresário Familiar, mas a análise do projeto indica ser mais funcional para os fruticul tores Parciais. Os recursos provenientes do Incentivo fiscal beneficiam apenas os fruticultores parciais e levam-nos a monopolizar a atividade beneficiando-se das excepcionais perspectivas de mercado existentes. O domínio da atividade e de mercado por esta categoria de produtores reflete no sistema referencial de açào do Empresário Familiar, orientando suas açöes e restringindo a prática da fruticultura. Nesse sentido, - projeto apresenta tendência a não proporcionar ao Empresário Familiar possibilidade de reorganizar seu sistema de produçào, via fruticultura.

Como conseqüência, a fruticultura como projeto atende às necessidades da sociedade e como atividade leva os Fruticultores Parciais e Empresários Familiares, respectivamen te, a uma integraçào total e parcial na sociedade, tendendo a provocar um maior desajuste sócioeconómico do setor Rural. A teoria utilizada atendeu aos objetivos do es tudo permitindo extrair inferências importantes para a com- 
preensäo dos problemas relacionados com a prática de novas atividades na agricultura.

Na revisão bibliográfica verificou-se que uma corrente atribuiu à subcultura a responsabilidade pelo atraso agropecuário e outra a fatores situacionais do setor rural. 0 atraso agropecuário, que este trabalno caracteriza como per manência do subsistema rural, relaciona-se com os fatores situacionais e externos, enquanto se impõem ao produtor e orientam sua ação; e com a cultura; enquanto esta representa um pä drão de orientação, fruto de experièncias anteriores proporcionadas por elementos situacionais. Nessa perspectiva a subcultura é fator de resistência à mudança, mas enquanto pro duto Internalizado, resultante de experièncias vivenciadas pelo produtor na situação. Não se pode, portanto, rotular a categoria de Empresário Familiar de resistentes à novas práticas agrícolas sem compreender o processo que origina este fato.

A presença do novo e do tradicional no sistema de produçäo indica que está em processo um redimensionamento dos padrões de conduta do Empresário Familiar. Isto confirma o que já foi demonstrado por GALJART (1976): a insuficiência dos conceitos tradicional e moderno para explicar a presença ou a falta de desenvolvimento no meio rural. A utilização ex clusiva de elementos novos, persistindo a forma de organização dos componentes situacionais, viria desintegrar o sistema de ação do Empresário Familiar. A atitude moderna do agri 
.114.

cultor, que alguns estudiosos caracterizam por uma aceitação de elementos novos no sistema social, se incorpora em termos absolutos, não lhe daria necessáriamente um padrão de vida em conformidade com os preceitos da sociedade.

o sistema de ação do Empresário Familiar integra-se mais eficientemente com a coexistência de instrumentos tradicionais e modernos de produção e esta modalidade de articulação com sistema social inclusivo é que permite a sua reprodução como categoria de produtor. 
.115 .

\section{BIBLIOGRAFIA}

BANCO CENTRAL DO BRASIL, Manual de Crédito Rural.

BURKE, T.J. e MOLINA FILHO, J. 1976. A adoção de Inovações na Agricultura. Uma abordagem sistêmica com ênfase nos fa tores perceptivos. Piracicaba, Departamento de Ciências Sociais Aplicadas, ESALQ/USP. 29p. (Série Estudos $n^{8} 21$ ).

CANDIDD, A., 1975. Os Parceiros do Rio Bonito. São Paulo,Li vraria. Duas Cidades, $284 p$.

CASTRO, A.M. e DIAS E. F9, 1975. Introducão ao Pensamento Sociológico. Rio de Janeiro, Livraria Eldorado Tijuca Ltda, $241 \mathrm{p}$.

DIEGUES JNR., M., 1964. Transformações da Comunidade Rural na América Latina. América Latina. Ano 7, 3:25. 
.116.

FERNANDES, F., 1976. Anotaçöes sobre o Capitalismo Agrário e a Mudança Social no Brasil. In: T. SZMRECSANYI e O. QUEDA, Org. Vida Rural e Mudansa Social, 2 : edição. São Paulo, Cia. Editora Nacional, p.105-120.

FERNANDES, F., 1972. Fundamentos Empirricos da Explicação Sociológica. São Paulo, Cia. Editora Nacional, 345 .

GALJART, B., 1976. Difusão Cultural, Modernização e Subdesen volvimento. In: T. SZMRECSANYI e O. QUEDA, Org. Vida Rural e Mudanfa Social, 2 ? edição. São Paulo, Cia. Editora Nacional, p.57-65.

HENTSCKE, R., (s.d.). Fruticultura de Clima Temperado no Bra sil. (mimeografado)

FREITAS, G.S., (s.d.). Incentivos fiscais em fruticultura de Clima Temperado. (mimeografado)

LEVY, M.J., 1975. Socialização. In: F.H. CARDOSO e O. IANNI, org. Homem e Sociedade, 9ă edição, São Paulo, Cia. Editora Nacional, p.60-62.

MALINOWSKI, 8., 1975. Uma Teoria Cientifica da Cultura, 3 . edição. Rio de Janeiro, Zahar Editores, $206 \mathrm{p}$.

MANCUSO, M.I.R., 1975. O Fenómeno da Persistência no Sistema Social Rural. Piracicaba, ESALQ/USP. $218 \mathrm{p}$. Dissertação de Mestrado.

MARTINS, J.S. Capitalismo e Tradicionalismo. São Paulo, Livraria Pioneira Editora, p.1-14. 
MERTON, R.K., 1970. Sociologia: Teoria e Estrutura. São Pau 10, Editora Mestre Jou, 758p.

MOLINA FILHO, J., 1976. "Classificação e Caracterização Sócio-Económica dos Agricultores". Revista de Economia Rural, XII Sober, ano XIV, tomo I, P.175-212.

MORANDINI, I., Coord., 1977. Normas Técnicas para Frutíferas Temperadas. (s.l.) Acarpa, 43p.

MUNIZ, J.N., 1974. Adoção de Inovações Tecnológicas no Subsistema Rural. Piracicaba, ESALQ/USP, 204p. (Dissertação de Mestrado).

ORREOA, J.M., 1972. Irati. Irati. Edipar, 252p.

PAIVA, R.M., 1971. "Modernização e Dualismo Tecnológico na Agricultura", Pesquisa e Planejamento. São Paulo, 2:3-64.

PARANÁ. Acarpa. 1975. Fruticultura. Curitiba, Acarpa.

PARANÁ. Acarpa. 1977. Estratégia de Ação por Projeto (Fruticultura). (S.L.) (s.ed.).

PARANÁ. Coordenação de Planejamento Estadual. 1967. II Cur so de Planejamento Governamental de Fruticultura para a Região de Iratí. (S.L.) (S. ed.).

PARANÁ. Secretaria de Estado da Agricultura. Departamento de Economia Rural, 1367. Acompanhamento da Situação Agro pecuária do Paraná (junho). Curitiba, (S. ed.). 
PARSONS, T. e SHILS, E., 1968. Hacia una Teoria General de Za accion. Buenos Aires, Editora Kapelusz S.A., 555p.

PARSONS, T., 1975. 0 conceito de Sistema Social. In: F.H. CARDOSO e 0. IANNI, org. Homem e Sociedade, 9? edição. São Paulo, Cia. Editora Nacional, p.47-55.

PARSONS, T. e outros, 1975. Papel e Sistema Social. In: F.H. CARDOSO e O. IANNI, Org. Homem e Sociedade, 9. edição. São Paulo, Cia. Editora Nacional, p.63-68.

PARSONS, T., 1975. Os componentes do Sistema Social. In: F.H. CARDOSO e O. IANNI, org. Homem e Sociedade, 9! edição. São Paulo, Cia. Editora Nacional, p.56-59.

PATRICK, G.F., 1975. Pobreza Rural no Brasil: Determinantes e Alternativas. São Paulo. Fundação Instituto de Pesqui sas Econōmicas.

PATRICK, G.F. e CARVALHO FILHO, J.G., 1975. Grupos de Pobre za na Agricultura Brasileira. Brasília. Relatório Preli minar Embrapa e Outros, p.48.

QUEIRÓZ, M.I.P., 1973. O Campesinato Brasileiro. São Paulo, Editora Vozes, $242 p$.

QUEIRÓZ, M.I.P. e GARCIA, L.F., 1968. O Sitiante Brasileiro e as transformações de sua situação sócio-Económica. In: Cadernos: Centro de Estudos Rurais e Urbanos. São Paulo, $n^{8} 1, p .109-131$.

ROCHER, G., 1976. Talcott Parsons e a Sociologia Americana. Rio de Janeiro, Livraria Francisco Alves Editora S.A.. $175 p$. 
ROGERS, E.M., 1962. Diffusion of Innovations. New York, Free Press. $367 p$.

ROGERS, E.M. e F. SHOEMAKER, 1971. Communication of Innovations: A Cross-Cultural Approach. New York, Free Press, $476 p$.

SCHRADER, A., 1974. Introdução à Pesquisa Social Empirica. Porto Alegre, Editora Globo, $275 p$.

SINGER, P., 1976. Agricultura e Desenvolvimento Económico. In: T. SZMRECSANYI e 0. QUEDA, org. Vida Rural e Mudansa Social, 2: Edição. São Paulo, Cia. Editora Nacional, p. $132-147$.

SOUZA, I.S.F., 1974. Adoção de Inovações e Eficiência Económica: Um Estudo da Racionalidade da Ação Empresarial Rural. ESALQ/USP, 16lp. (Dissertação de Mestrado).

Stavenhagen, R., 1976. A Comunidade Rural nos Países Subdesenvolvidos. In: T. SZMTRECSANYI e O. QUEDA, Org. Vida Rural e Mudansa Social, 2 : edição. São Paulo, Cia. Edito ra Nacional, p.26-37.

SAMANIEGO, L.C., 1971. Aspectos Sociológicos para um Nuevo Enfoque de La Extenção Rural. Desarrolzo Rural en Las Américas. Costa Rica, 3:43-53.

WOLF, E.R., 1976. Sociedades Camponesas, 2? edição. Rio de Janeiro, Zahar Editores, $150 p$. 
.120.

8. $A N E \times O S$ 
ANEXO 1 - Empresários Familiares Fruticultores.

\begin{tabular}{|c|c|c|c|c|}
\hline $\begin{array}{l}N^{8} \text { DE } \\
\text { ORDEM }\end{array}$ & ENTR. & $\begin{array}{c}N^{8} D E \\
\text { PÉS }\end{array}$ & VARIEDADE & $\begin{array}{l}\text { AREA DA PRO- } \\
\text { PRIEDADE (ha) }\end{array}$ \\
\hline 1 & 1 & $\begin{array}{l}45 \\
11 \\
16\end{array}$ & $\begin{array}{l}\text { pêssego } \\
\text { ameixa } \\
\text { diversos }\end{array}$ & 24,0 \\
\hline 2 & 2 & $\begin{array}{r}240 \\
1050\end{array}$ & $\begin{array}{l}\text { pêssego } \\
\text { maçã }\end{array}$ & 24,0 \\
\hline 3 & 3 & 150 & pêssego & 7,2 \\
\hline 4 & 4 & $\begin{array}{r}160 \\
20\end{array}$ & $\begin{array}{l}\text { péssego } \\
\text { amei } \times \text { a }\end{array}$ & 81,2 \\
\hline 5 & 6 & 240 & pēssego & 26,4 . \\
\hline 6 & 7 & 112 & pêssego & 38,4 \\
\hline 7 & 9 & 150 & pēssego & 24,0 \\
\hline 8 & 13 & 100 & pêssego & 40,8 \\
\hline 9 & 18 & 100 & pêssego & 96,0 \\
\hline 10 & 19 & 62 & pēssego & 6,6 \\
\hline 11 & 22 & $\begin{array}{l}23 \\
11\end{array}$ & $\begin{array}{l}\text { pêssego } \\
\text { ameixa }\end{array}$ & 21,6 \\
\hline 12 & 21 & 50 & ameixa & 32,5 \\
\hline 13 & 23 & $\begin{array}{r}163 \\
50\end{array}$ & $\begin{array}{l}\text { pêssego } \\
\text { maçã }\end{array}$ & 19,2 \\
\hline 14 & 24 & 30 & pêssego & 21,6 \\
\hline 15 & 27 & $\begin{array}{l}60 \\
50 \\
30\end{array}$ & $\begin{array}{l}\text { pêssego } \\
\text { maçã } \\
\text { ameixa }\end{array}$ & 66,2 \\
\hline 16 & 41 & $\begin{array}{r}277 \\
31 \\
20\end{array}$ & $\begin{array}{l}\text { Pêssego } \\
\text { ameixa } \\
\text { maçã }\end{array}$ & 14,5 \\
\hline 17 & 42 & $\begin{array}{r}400 \\
40 \\
130\end{array}$ & $\begin{array}{l}\text { pêssego } \\
\text { amei xa } \\
\text { maçã }\end{array}$ & 72.0 \\
\hline 18 & 44 & $\begin{array}{r}108 \\
100 \\
60\end{array}$ & $\begin{array}{l}\text { pêssego } \\
\text { amei } \times a \\
\text { maçã }\end{array}$ & 41,0 \\
\hline 19 & 59 & 316 & pêssego & 23,6 \\
\hline
\end{tabular}


ANEXO 2 - Fruticultores Parciais.

\begin{tabular}{|c|c|c|c|c|c|}
\hline $\begin{array}{l}N^{9} \text { OE } \\
\text { ORDEM }\end{array}$ & ENTR. & $\begin{array}{c}N^{9} \text { DE } \\
\text { PES }\end{array}$ & $\begin{array}{l}\text { VARIE - } \\
\text { DAUES }\end{array}$ & $\begin{array}{l}\text { ĀREA DA PRO } \\
\text { PRIEDAOE }\end{array}$ & OCUPAÇÃO \\
\hline 1 & 29 & 90 & pèssego & 14,4 & Pedreiro \\
\hline 2 & 30 & $\begin{array}{r}100 \\
15\end{array}$ & $\begin{array}{l}\text { pẽssego } \\
\text { amei } \times a\end{array}$ & 87,4 & Comerciante \\
\hline 3 & 38 & $\begin{array}{r}1400 \\
200\end{array}$ & $\begin{array}{l}\text { péssego } \\
\text { amei } \times a\end{array}$ & 176,0 & Reflorest. \\
\hline 4 & 39 & $\begin{array}{r}200 \\
20 \\
40\end{array}$ & $\begin{array}{l}\text { pêssego } \\
\text { maçã } \\
\text { ameixa }\end{array}$ & 45,6 & Transporte \\
\hline 5 & 40 & $\begin{array}{l}780 \\
262 \\
140\end{array}$ & $\begin{array}{l}\text { maçã } \\
\text { pẽssego } \\
\text { ameixa }\end{array}$ & 9,6 & Ferreiro \\
\hline 6 & 43 & 300 & pêssego & 1,2 & Madeireiro \\
\hline 7 & 45 & $\begin{array}{r}210 \\
140 \\
30\end{array}$ & $\begin{array}{l}\text { pêssego } \\
\text { ameixa } \\
\text { meçã }\end{array}$ & 100,0 & Comerciante \\
\hline 8 & 46 & $\begin{array}{l}50 \\
140 \\
140\end{array}$ & $\begin{array}{l}\text { maçã } \\
\text { pẽs sego } \\
\text { ameixa }\end{array}$ & 13,0 & Transporte \\
\hline 9 & 47 & $\begin{array}{l}103 \\
190\end{array}$ & $\begin{array}{l}\text { pêssego } \\
\text { maçã }\end{array}$ & 7,0 & Industrial \\
\hline 10 & 48 & $\begin{array}{r}120 \\
35\end{array}$ & $\begin{array}{l}\text { pèssego } \\
\text { ameixa }\end{array}$ & 40,0 & Comerciante \\
\hline 11 & 49 & $\begin{array}{r}170 \\
70 \\
40\end{array}$ & $\begin{array}{l}\text { pëssego } \\
\text { ameixa } \\
\text { maçã }\end{array}$ & 89,5 & Juiz \\
\hline 12 & 50 & $\begin{array}{l}100 \\
100\end{array}$ & $\begin{array}{l}\text { pêssego } \\
\text { amei xa }\end{array}$ & 10,0 & Func. Público \\
\hline 13 & 51 & $\begin{array}{r}100 \\
30\end{array}$ & $\begin{array}{l}\text { pêssego } \\
\text { amei } \times a\end{array}$ & 1,8 & Radialista \\
\hline
\end{tabular}


.123.

ANEXO 2 - Continuação.

\begin{tabular}{|c|c|c|c|c|c|}
\hline $\begin{array}{l}\text { NQ DE } \\
\text { ORDEM }\end{array}$ & ENTR. & $\begin{array}{l}N^{8} \text { DE } \\
\text { PESS }\end{array}$ & $\begin{array}{l}\text { VARIE - } \\
\text { DADES }\end{array}$ & $\begin{array}{c}\text { ARREA DA PRO } \\
\text { PRIEDADE }\end{array}$ & DCUPAÇĀO \\
\hline 14 & 52 & $\begin{array}{r}150 \\
50\end{array}$ & $\begin{array}{l}\text { péssego } \\
\text { ameixa }\end{array}$ & 18,0 & Comerciante \\
\hline 15 & 53 & 130 & pēssego & 90,0 & Comerciante \\
\hline 16 & 54 & 106 & pêssego & 19,3 & Comerciante \\
\hline 17 & 55 & $\begin{array}{l}900 \\
100\end{array}$ & $\begin{array}{l}\text { péssego } \\
\text { ameixa }\end{array}$ & 970,0 & Comerciante \\
\hline 18 & 56 & $\begin{array}{l}80 \\
30\end{array}$ & $\begin{array}{l}\text { pêssego } \\
\text { amei } \times \text { a }\end{array}$ & 193,0 & Industrial \\
\hline 19 & 58 & $\begin{array}{l}91 \\
60\end{array}$ & $\begin{array}{l}\text { pêssego } \\
\text { maçã }\end{array}$ & 170,0 & Oleiro \\
\hline 20 & 50 & 350 & pêssego & 34,0 & Madeireiro \\
\hline 21 & 61 & $\begin{array}{r}13940 \\
4600\end{array}$ & $\begin{array}{l}\text { pês sego } \\
\text { maçã }\end{array}$ & 75,0 & Madeireiro \\
\hline 22 & 62 & 98000 & maçã & 342,0 & Reflorest. \\
\hline 23 & 63 & 250 & pêssego & 307,0 & Médico \\
\hline
\end{tabular}


ANEXO 3 - Questionário para coleta de dados qualificáveis.

1- Informante:

2- Ocupação principal:

3- Area da propriedade: total da unidade:

4- Uso da terra: proprietário ( ) arrend. ( ) parceiro ( ) 5- Mão-de-obra utilizada:

M. O. Idade e/h

familiar

idade $\quad h .-m$.

$10-14$

0,5

0,5

$15-17$

0,8

0,8

assalariada

$18-59$

1,0

0,8

$60+$

0,8

0,5

6- Dados de Produçäo:

\begin{tabular}{|l|l|l|l|l|l|} 
Culturas & ärea & qdade.prod. & qdade venda & preço & qdade cons. \\
\hline & & & & & \\
\hline & & & & & \\
\hline & & & & & \\
\hline & & & & & \\
\hline & & & & & \\
\hline
\end{tabular}

7- Cultura de Frutas:
$n^{8}$ de pés
espécie
área
ano de plantio 